\title{
Habitat structure and biological characteristics of a maerl bed off the northeastern coast of the Maltese Islands (central Mediterranean)
}

\author{
Marija Sciberras • Miraine Rizzo • Jael R. Mifsud • \\ Katielena Camilleri • Joseph A. Borg • \\ Edwin Lanfranco • Patrick J. Schembri
}

Received: 22 April 2009 /Revised: 29 May 2009 / Accepted: 2 June 2009 /Published online: 25 June 2009

(C) Senckenberg, Gesellschaft für Naturforschung and Springer 2009

\begin{abstract}
Forty stations within a $20 \mathrm{~km}^{2}$ Maltese maerl bed were sampled by grab to gather data on sediment granulometry and the percentage mass, sphericity, and morphotype of rhodoliths. Two stations were monitored between July 1996 and April 1998 to study temporal variation in species diversity and abundance of the epi- and endo-benthos. Maerl was commonest at $51-90 \mathrm{~m}$ depth with $20-39 \%$ live rhodoliths in central parts of the maerl bed, while the peripheral parts had less than $20 \%$ live rhodoliths. The most abundant rhodolith morphotypes were branching forms and those with a rugged surface. The maerl bed proved to have high species diversity with 244 animal and 87 algal taxa recorded; molluscs, crustaceans, and annelids were the dominant taxa in the endobenthos, and bryozoans and sponges in the epibenthos. Community composition, rhodolith morphology and sediment characteristics at the two sites were related to differences in the hydrodynamic regime resulting from seabed topographical heterogeneity.
\end{abstract}

Keywords Maerl · Malta Central Mediterranean · Coralline algae $\cdot$ Epibenthos $\cdot$ Endobenthos

\footnotetext{
Electronic supplementary material The online version of this article (doi:10.1007/s12526-009-0017-4) contains supplementary material, which is available to authorized users.
}

M. Sciberras $(\bowtie) \cdot$ M. Rizzo $\cdot$ J. R. Mifsud $\cdot$ K. Camilleri

J. A. Borg • E. Lanfranco $\cdot$ P. J. Schembri

Department of Biology, University of Malta,

Msida MSD2080, Malta

e-mail: marija_sciberras@yahoo.com

P. J. Schembri

e-mail: patrick.j.schembri@um.edu.mt

\section{Introduction}

Maerl sediments are characterized by accumulations of calcareous rhodophytes (mostly Corallinaceae but also Peyssonneliaceae), that form habitats with a high species diversity over broad geographical and depth ranges (Barberá et al. 2003; Foster 2001; Freiwald and Henrich 1994). In European waters, these biogenic sediments occur throughout the Mediterranean and are patchily distributed along the Atlantic coast from Portugal to Norway, although they are rare in the English Channel, Irish Sea, North Sea, and Baltic Sea (BIOMAERL team 1998; De Grave et al. 2000; Hall-Spencer 1998). Light, salinity and temperature seem to be the main environmental factors influencing the distribution of maerl beds (Littler et al. 1991; Steller et al. 2007; Wilson et al. 2004), provided there is sufficient water motion to prevent rhodolith burial (Marrack 1999; Wilson et al. 2004).

Maerl beds are biodiversity 'hot-spots' as they enhance biological and functional diversity of coastal sediments (BIOMAERL Team 1998; Bordehore et al. 2003; Grall et al. 2006; Jackson et al. 2004; Steller et al. 2003). Rhodolith-forming algae have been described as 'ecological engineers' (Jones et al. 1994; Steller et al. 2003) as they provide a variety of ecological niches for a highly diverse suite of species, including epibenthic, epiphytic, cryptic, and infaunal species (Amado-Filho et al. 2007; De Grave 1999; De O Figueiredo et al. 2007; Foster et al. 2007; Grall et al. 2006; Kamenos et al. 2004a; Peña and Bárbara 2008a, b; Riul et al. 2009; Steller et al. 2003).

Maerl beds are threatened by numerous anthropogenicrelated exploitative activities including dredging, eutrophication, fishing, and mariculture (Ballesteros 2006; Barberá et al. 2003; Bordehore et al. 2003; Grall and Hall-Spencer 
2003; Hall-Spencer 1998; Hall-Spencer and Moore 2000; Massuti et al. 1996; Riul et al. 2008). In the Maltese Islands, the main threat to maerl beds is from bottom trawling, although changes in the sedimentary regime due to coastal development may pose an additional threat (Barberá et al. 2003; Borg et al. 1999). Loss of maerl habitat is exacerbated by the slow rate of growth of the constituent rhodoliths (Blake and Maggs 2003; Bosence and Wilson 2003), which is far outstripped by anthropogenic extraction and disruption. The conservation value of these ecologically fragile systems in European waters is recognized under EU legislation (Council Directive 92/43/ EEC , 1992) and international conventions (Convention for the protection of the Mediterranean Sea against pollution, 1976; Bern Convention, 1996; OSPAR convention, 1998) (Airoldi and Beck 2007; Barberá et al. 2003). A special Action Plan for the protection of Mediterranean coralligenous and maerl assemblages has been recently adopted within the framework of the United Nations Environment Programme's Mediterranean Action Plan (UNEP-MAP) (Agnesi et al. 2009).

Maerl beds cover large areas off the Maltese Islands at depths of ca. 40-100 m (Borg et al. 1998; Dimech et al. 2004). Two extensive maerl beds are known to date; one located in 1993 off the rocky shoal of 'is-Sikka l-Bajda' off the northeastern coast of Malta and extending northeastward off Gozo (Borg et al. 1998), and the other located in 2004 off the southeastern coast of Malta at a maximum water depth of $85 \mathrm{~m}$ (Dimech et al. 2004). Although Borg et al. (1998) provided the first scientific record of maerl in the Maltese Islands, local fishermen have long been aware of the presence of such beds, and commonly refer to mearl as ramel haj (Maltese for "living sediment") owing to the high productivity of such beds.

For effective conservation management of maerl habitats, in-depth studies on the distribution, biotic diversity and community structure of maerl beds are required. The aim of the present work was to determine the spatial extent, physical characteristics, and taxonomic and functional diversity of the Maltese maerl bed off the northeastern coast of the Maltese Islands to provide a basis for future studies designed to better understand aspects of function, diversity and productivity of this maerl bed.

\section{Material and methods}

Characterization of the maerl bed

In April 1996, $0.1 \mathrm{~m}^{2}$ Van Veen grabs were taken approximately 0.5 nautical miles apart along 12 transects laid 1 nautical miles apart and located perpendicular to the NE coast of the islands of Gozo and Malta (Fig. 1). The results of this survey revealed an extensive maerl bed at $30-100 \mathrm{~m}$ depth, ca. 10 nautical miles long and between 1 and 3 nautical miles wide, and covering a seabed area of around $20 \mathrm{~km}^{2}$ (Fig. 1). Rhodoliths collected in the grab samples were identified on the basis of gross morphology using Giaccone (1972-1973), Hamel and Lemoine (1953), and Preda (1908), and a selection of specimens were checked using a combination of light microscopy and scanning electron microscopy. Rhodoliths were classified into six morphotypes (see Fig. 2), and the collective weight of each morphotype was determined $( \pm 0.1 \mathrm{~g})$ for each grab sample, and expressed as a percentage of the total sediment weight. Rhodoliths were divided into non-nucleated rhodoliths, which are composed entirely of coralline algal tissue, and nucleated rhodoliths, which have a non-algal core of inorganic or biogenic origin (Foster 2001; Freiwald 1995; Freiwald and Henrich 1994), and the percentage composition of each was determined. Rhodolith shape was determined by measuring the longest intercept $(a)$, the largest axis at right angles to axis a $(b)$, and the widest part of the plane at right angles to both axes $a$ and $b(c)$, for 50 randomly picked nucleated rhodoliths and 50 non-nucleated rhodoliths for each station. The ratios $b / a$ and $c / b$ were used to read sphericity $(\Psi)$ values from the graph given in Krumbein (1941). Each rhodolith was assigned to one of the following sphericity classes: $\leq 0.3,0.31-0.40,0.41-$ $0.50,0.51-0.60,0.61-0.70,0.71-0.80,0.81-0.90,0.91-$ 1.0. Standard granulometric analysis of the non-biogenic sediment was carried out by sieving samples through nested test-sieves (Endecott) of mesh sizes $8 \mathrm{~mm}, 4 \mathrm{~mm}, 2 \mathrm{~mm}$, $1 \mathrm{~mm}, 500 \mu \mathrm{m}, 250 \mu \mathrm{m}, 125 \mu \mathrm{m}$, and $63 \mu \mathrm{m}$, following the procedure given in Buchanan and Kain (1971).

Characterization of the gross 3-D structure of the maerl bed

Three $10 \mathrm{~cm}$ diameter, $15 \mathrm{~cm}$ long cores were collected from Sites 1 and 2 (Fig. 1) by SCUBA divers and lifted upright to the surface. One core sample from each site was cast with Crystic Polyester Resin 2-406 PA (Scott Bader, U.K.) to determine the three-dimensional structure of the rhodolith bed, the other two cores were frozen at $-18^{\circ} \mathrm{C}$, sectioned into $2 \mathrm{~cm}$ layers, and dried at $100^{\circ} \mathrm{C}$. When dry, each sediment fraction was graded separately by dry sieving through nested sieves as detailed above. The percentage weight of each sediment fraction was used to calculate the mean, mode and median $\left(\mathrm{D}_{50}\right)$ particle size, interquartile deviation $\left(\mathrm{D}_{75}-\mathrm{D}_{25}\right)$, sorting coefficient, kurtosis, skewness and the proportion of gravel, sand and mud, using the GRADISTAT v.4 software (Blott and Pye 2001).

Six $0.1 \mathrm{~m}^{2}$ Van Veen grab samples were also collected from each of Sites 1 and 2 during July 1996. For each grab sample, 50 randomly chosen rhodoliths were weighed and measured along three perpendicular axes, and the total 


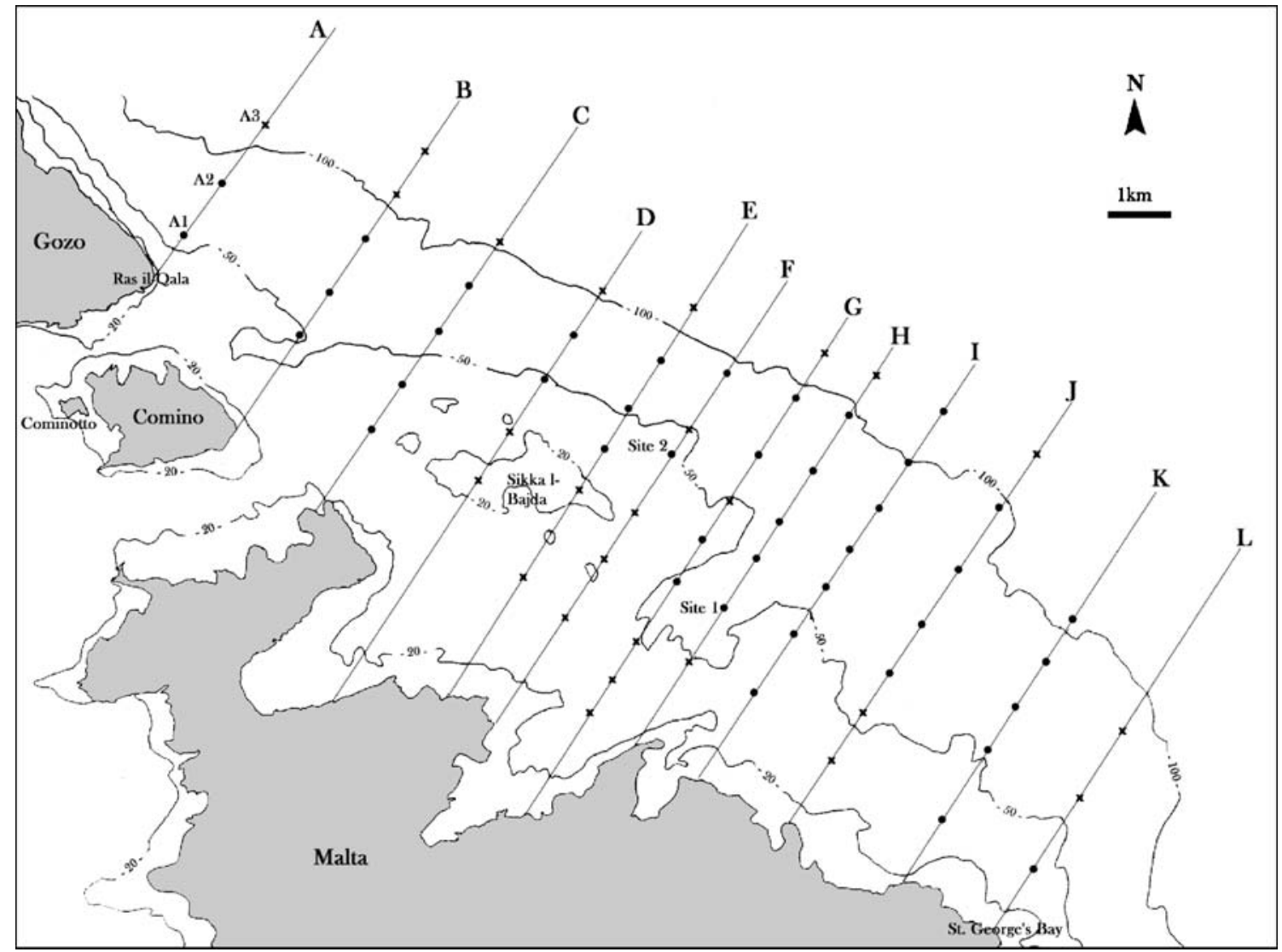

Fig. 1 Bathymetry northeast of the Maltese Islands showing the location of the 12 transects $(A-L)$ and a rocky shoal (Sikka l-Bajda). Stations along each transect are labelled 1,2 ...n, where 1 is the station closest to the coast and $\mathrm{n}$ is the furthest one away (in the figure, labels are given for Transect $A$ only, as an example). Stations where no live calcareous algae were collected are marked $(\times)$ while $(\bullet)$ indicates the presence of live calcareous algae. Sites 1 and 2 were sampled repeatedly between 1996 and 1998
Morph A
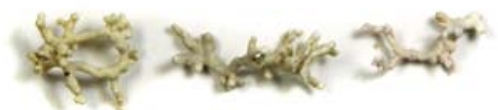

Morph B

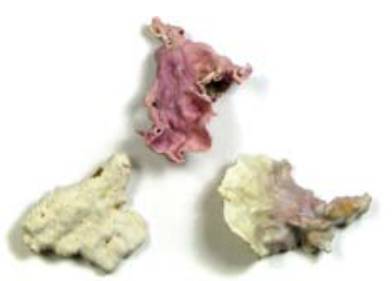

Morph C

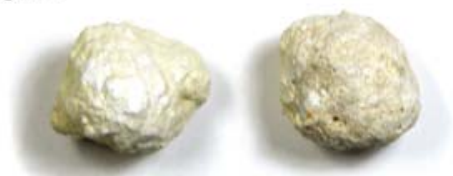

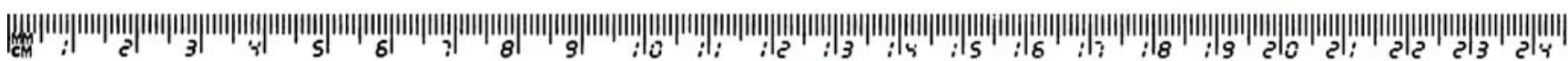

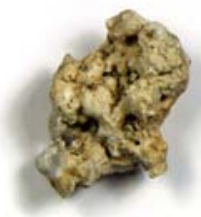

Morph D

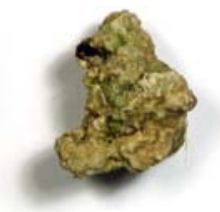

Morph E

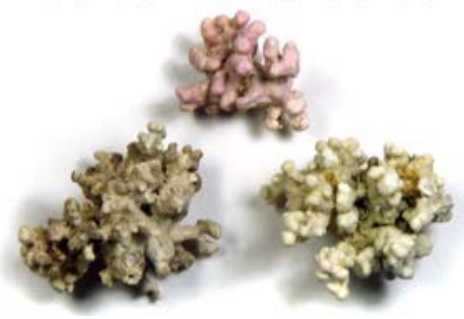

Morph F

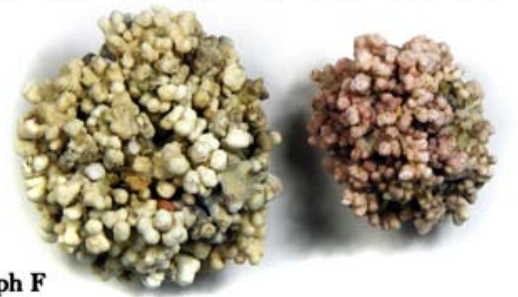

Fig. 2 Rhodolith morphotypes: Morph $A$ (rhodoliths with very thin and fine branches), Morph $B$ (laminar, smooth rhodoliths including Peyssonnelia sp.), Morph $C$ (spherical rhodoliths having a smooth surface), Morph $D$ (rhodoliths having a very rugged and rough surface), Morph E (rhodoliths having long, medium thin branches open branching), Morph $F$ (rhodoliths having short finger-like branches - closed branching) 
volume of 50 rhodoliths was obtained by water displacement in a measuring cylinder.

\section{Sampling of biota}

Three $0.1 \mathrm{~m}^{2}$ Van Veen grab samples were collected from Sites 1 and 2 once every 3 months between July 1996 and April 1998. The samples were sieved through $1 \mathrm{~mm}$ sieves, sorted, and the algae, molluscs, crustaceans, polychaetes and echinoderms identified to the lowest possible taxon. Estimates of macrofaunal abundance were expressed as number of individuals per $0.1 \mathrm{~m}^{2}$ grab, while those of algae as wet weight $(\mathrm{g})$ per $0.1 \mathrm{~m}^{2}$ grab. For algae with sediment-binding rhizoids (e.g., Flabellia petiolata), only the laminae were weighed, and the abundance of species with fine ramifying filaments that entangle sediment particles and rhodoliths (e.g., Womersleyella setacea) was estimated using a 4-point percentage cover scale $(<25 \%, 25-50 \%, 51-75 \%$, and $>75 \%)$. Sixty rhodoliths from two of the three grab samples collected from Sites 1 and 2 during July and October 1997 and January and April 1998 were examined to determine epifauna growing on rhodoliths. Estimates of rhodolith epifauna abundance were expressed as number of epiphytic individuals per $100 \mathrm{~cm}^{2}$ of rhodolith surface. For bryozoans, the whole colony was taken to represent a single unit. Sphericity was calculated for a sample of 125 rhodoliths to investigate if any correlation exists between sphericity and the number of epiphytic fauna.

\section{Environmental conditions}

Physical parameters of the water column, including water transperancy, temperature, salinity, and total suspended matter, were measured at Sites 1 and 2 at approximately monthly intervals, weather permitting. A Secchi disc was used to measure water transperancy, and a temperaturesalinity probe [Kent EIL 5005] was used to measure the salinity and temperature at every $5 \mathrm{~m}$ depth interval. A 5-1 sample of water was collected from $1 \mathrm{~m}$ depth below the surface using a Van Dorn water sampler, and later filtered under vacuum through a $45 \mu \mathrm{m}$ cellulose nitrate membrane of known weight. The filter was dried at $100^{\circ} \mathrm{C}$ to determine the amount of suspended solids in the water column, and then incinerated in a muffle furnace at $550^{\circ} \mathrm{C}$ to determine the amount of organic matter.

\section{Data analysis}

The 42 stations found to contain live rhodoliths (see Fig. 1 and Appendix 1) were divided into two groups based on a two-step Cluster analysis (Clusters 1 and 2), using Schwarz's Bayesian clustering criterion and percentage mass of rhodoliths and depth of station as continuous variables. One-way analysis of variance (ANOVA) was used to determine differences in the proportion of rhodoliths and non-biogenic sediment characteristics between the two clusters. Rhodolith samples were composed primarily of nucleated rhodoliths (percentage mass of nucleated vs non-nucleated rhodoliths; $79.06 \pm 27.28 \%$ vs. $20.94 \pm$ $27.28 \%, n=40$ ), hence the combined values of nonnucleated and nucleated rhodoliths were used for analysis of rhodolith sphericity and morphotype. One-way ANOVAs were used to determine differences between rhodolith sphericity and water depth for 5 stations (K1-K5) along a depth gradient and between this attribute and sampling station position for 11 stations (A1, B2, C4, D4, E5, F6, G7, H5, I4, J4, K3) at more or less constant depth $(60-71 \mathrm{~m})$. Differences between rhodolith morphotype (6 levels corresponding to morphs $\mathrm{A}-\mathrm{F}$ ) and station clusters (Clusters 1 and 2) were determined using two-way ANOVA.

Temporal and spatial differences in total abundance of macrofauna were tested using two-way ANOVA. A dominance index $(\mathrm{dm})$ defined as $\mathrm{dm}=100(n / N)$, where $n$ is the number of specimens of a species and $N$ is the total number of individuals collected, was used to identify the dominant species in the maerl bed faunal assemblage. The dominance index was also calculated for macroalgae, using wet weight values. Multivariate analysis was carried out using PRIMER v.6 (Clarke and Warwick 2001) on fourthroot transformed abundance data for macrofauna to produce a Bray-Curtis sample similarity matrix. The faunal assemblage composition between sampling sites and seasons was compared using an a priori two-way crossed analysis of similarity (ANOSIM).

To assess the functional diversity of the maerl bed, species were grouped in the following feeding categories: suspension feeders, deposit feeders, macrograzers, micrograzers, predators, scavengers, multifunctional feeders, and others (comprising commensals, parasites, and one bivalve species, Solemya togata, that feeds by direct absorption). Species with insufficient information in the literature on their feeding biology were assigned to the 'unknown' category. Those described to feed both by scavenging and predation, and by suspension and deposit feeding were included as separate categories: 'predator/scavenger' and 'suspension/deposit feeder', respectively. Information on the feeding ecology of the identified species was mainly drawn from Day (1967), Gambi et al. (1985), Graham (1988), Hughes (1986), Kohn (1983), Marshall and Orr (1960), Morton (1983), Nicol (1967), Pérès (1982), and Scipione (1999). Kruskal-Wallis tests were used to test for significant differences in percentage total abundance and number of species within each feeding category between Sites 1 and 2. 


\section{Results}

Environmental conditions

No significant differences were detected in water temperature, salinity, transperancy, total suspended matter, and percentage suspended organic matter between Sites 1 and 2 . Mean surface water temperature was $20.96 \pm 3.91^{\circ} \mathrm{C}$ for Site 1 and $21.10 \pm 3.90^{\circ} \mathrm{C}$ for Site 2 , and the mean bottom water temperature was $18.17 \pm 1.49^{\circ} \mathrm{C}$ and $18.76 \pm 2.37^{\circ} \mathrm{C}$ for Sites 1 and 2 , respectively. Surface and bottom salinity averaged $37.52 \pm 0.17$ at both sites. Levels of mean total suspended matter and suspended organic matter were $1.49 \pm 0.35 \mathrm{mg} / \mathrm{L}$ and $32.23 \pm 17.84 \%$ at Site 1 , and $1.71 \pm 0.43 \mathrm{mg} / \mathrm{L}$ and $37.99 \pm 23.27 \%$ at Site 2, respectively. Mean water transperancy averaged $23.43 \pm 3.42 \mathrm{~m}$ at Site 1 and $24.08 \pm$ $3.82 \mathrm{~m}$ at Site 2 .

\section{Characterization of the maerl bed}

Live maerl-forming calcareous algae were collected from a depth ranging between $31 \mathrm{~m}$ and $103 \mathrm{~m}$ (Appendix 1), but occurred more commonly at a water depth of 51-90 m. Five maerl-forming algal species were identified from the study area; four Corallinaceae: Lithothamniom corallioides (P.L. Crouan \& H.M. Crouan) P.L. Crouan \& H.M. Crouan, Phymatolithon calcareum (Pallas) W.H. Adey \& D.L. McKibbin, Neogoniolithon brassica-florida (Harvey) Setchell \& L.R. Mason, and Mesophyllum lichenoides (J. Ellis) M. Lemoine; and one Peyssonneliaceae: Peyssonnelia sp. The overall mean percentage mass $( \pm$ SD) of rhodoliths was $13.44 \pm 11.58 \%$, and reached a maximum of $39 \%$ (Appendix 1). A significant positive correlation, albeit weak, was found between depth of station and percentage mass of rhodoliths (Pearson-moment correlation coefficient $=$ 0.345; $p=0.029, n=40$ ). Two-step Cluster analysis generated two clusters: (1) Cluster 1, composed of 13 stations (B2, D4, E5, F6, G7, G8, H6, I7, J4, J5, J6, K4, K5), and (2) Cluster 2 , composed of the remaining 27 stations. Stations in Cluster 1 had higher percentage mass of rhodoliths and percentage content of gravel (Table 1) and a significantly higher mean particle diameter $\left(\mathrm{M}_{\mathrm{d}}\right)(F=6.26, p=0.017)$ than stations in Cluster 2.

Rhodolith shape varied from non-spherical to spherical; however, for ca. $50 \%$ of the rhodoliths, sphericity ranged between 0.6 and 0.8 (Fig. 3) indicating that rhodoliths show a tendency towards a spherical shape. Sphericity did not change significantly with water depth $(F=0.72, p=0.58$, $n=5)$, but differed significantly between different sampling station locations $(F=6.5, p<0.001, n=11)$. Rhodoliths collected from stations located closer to is-Sikka ilBajda', particularly those from stations D4, E5, F6, and G7 (refer to Fig. 1), were found to have higher sphericity
Table 1 Mean $( \pm$ SD) percentage mass of the live rhodoliths ( $\%$ mass rhodoliths), water depth (m), mass of gravel (\%), mass of sand (\%), mass of mud (\%), mean particle diameter (phi), and sorting coefficient, for the two station clusters generated by two-step cluster analysis

\begin{tabular}{lll}
\hline & Cluster 1 & Cluster 2 \\
\hline Sample size $(N)$ & 13 & 27 \\
Depth $(\mathrm{m})$ & $78.62 \pm 15.08$ & $57.56 \pm 12.22$ \\
\% mass rhodoliths & $26.35 \pm 9.81$ & $7.22 \pm 5.76$ \\
Gravel content (\%) & $58.09 \pm 17.71$ & $27.84 \pm 13.46$ \\
Sand content $(\%)$ & $40.6 \pm 17.81$ & $69.80 \pm 13.66$ \\
Mud content $(\%)$ & $1.31 \pm 0.91$ & $2.36 \pm 2.54$ \\
Mean particle diameter $\left(\mathrm{M}_{\mathrm{d}}\right)$ & $-0.58 \pm 0.87$ & $0.11 \pm 0.75$ \\
Sorting coefficient $\left(\mathrm{Q}_{\mathrm{d}}\right)$ & $1.31 \pm 0.32$ & $0.94 \pm 0.56$
\end{tabular}

values $(0.61-0.8)$, than rhodoliths collected from peripheral stations $(0.41-0.6)$. The predominant rhodolith morphotypes were morphs D (rhodoliths having a very rugged and rough surface), E (open branching form) and $\mathrm{F}$ (closed branching form) (Fig. 4). ANOVA using data for rhodolith percentage mass between Clusters 1 and 2 and rhodolith morphotype indicated a significant interaction between the two factors (Table 2). Morphotypes D and F had a higher percentage mass in Cluster 1 stations (mean depth: 78.62 \pm $15.08 \mathrm{~m}$ ) compared to Cluster 2 stations (mean depth: $57.56 \pm 12.22 \mathrm{~m}$ ), which had approximately the same percentage mass of morphotypes D, E, and F (Fig. 4).

\section{3-D structure of the maerl bed}

The core samples revealed a loose layer of sediment down to about $7 \mathrm{~cm}$ from the surface, which was mostly composed of rhodolith-derived calcareous sand with small gastropod shells and other biogenic fragments, including echinoderm spines, bivalve shells, serpulid tubes, bryozoan tests, and foraminiferans. Interstitial sediment was poorly sorted, more so at Site 1 than Site 2, and was primarily composed of medium rhodolith-derived gravel $(<2->1 \mathrm{~mm})$ and medium and coarse sands (>500 $\mu \mathrm{m})$ (Table 3). Sediment particles smaller than $500 \mu \mathrm{m}$ made up less than $20 \%$ of the core samples. Rhodoliths from Site 2 were larger and heavier than rhodoliths from Site 1 (Table 4).

\section{Characterization of biota}

A total of 331 species (244 macroinvertebrates and 87 algae) were collectively recorded from Sites 1 and 2 . Species which could not be identified down to genus or species level due to lack of taxonomic expertise were given a higher order taxonomic rank such as family (Phyllodocidae, Paraonidae, Sabellidae, Nereidae). Appendix 2 presents the full list of the species identified. Molluscs (namely gastro- 


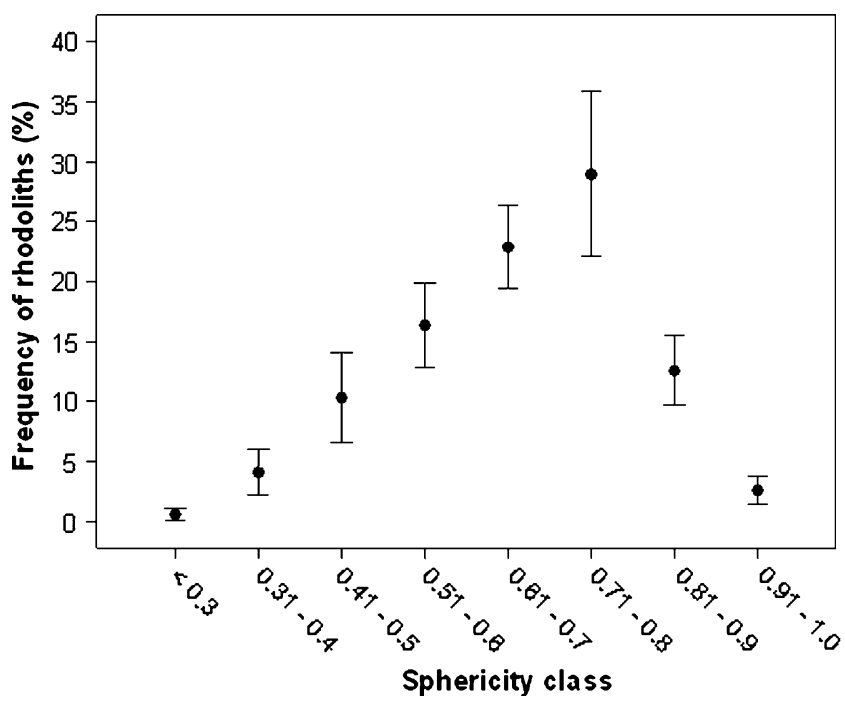

Fig. 3 Mean percentage frequency distribution of rhodoliths in different sphericity classes. Error bars represent the 95\% confidence intervals

pods and bivalves), crustaceans, and annelids (particularly polychaetes) were the dominant taxa in terms of number of species in the endobenthos $(45,25,64$, and 57 , respectively), and algae, bryozoans, and sponges in the epibenthos $(87,16$, and 14 , respectively). The overall number of species was significantly higher at Site 1 than Site 2 (Table 5), owing in part to a more diverse macroalgae species assemblage at Site 1 (Table 6). Macroinvertebrate abundance was higher at Site 2 , whereas biomass of macroalgae was higher at Site 1 (Table 6). Although macroinvertebrate abundance was significantly different across seasons (Table 5(b)), no

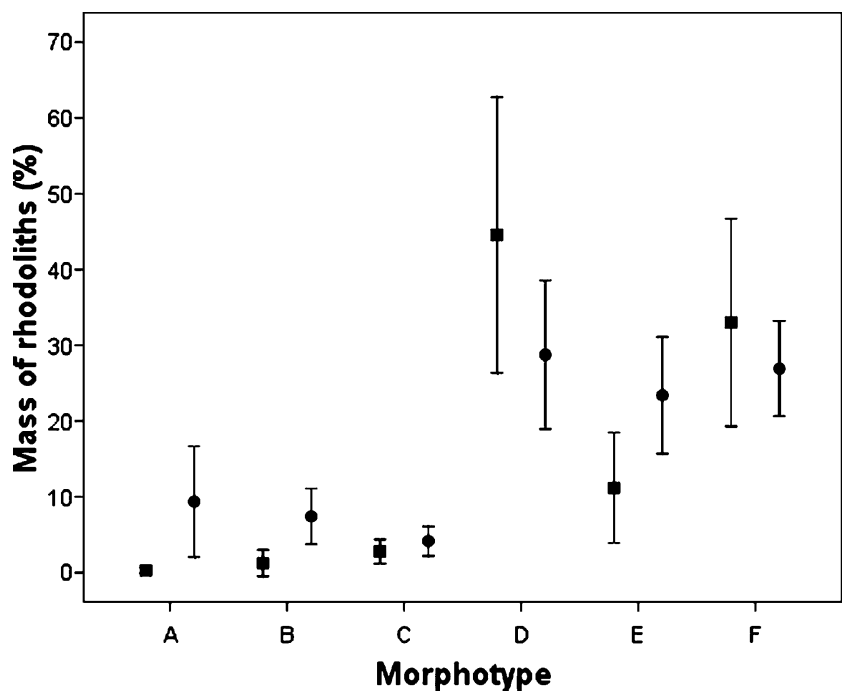

Fig. 4 Mean percentage mass of rhodoliths for each of the six morphotypes and the two clusters generated by two-step cluster analysis (black square Cluster 1, black circle Cluster 2). Error bars represent the $95 \%$ confidence intervals
Table 2 Two-way ANOVA results for significance testing of percentage mass of rhodoliths between station clusters generated by two-step cluster analysis (Clusters 1 and 2) and morphotypes (Morphs $\mathrm{A}-\mathrm{F})$

\begin{tabular}{lllll}
\hline & $d f$ & MS & $F$ & $P$ \\
\hline Morphotype & 5 & 7308.32 & 26.40 & $<0.001$ \\
Clusters $(1,2)$ & 1 & 70.16 & 0.25 & 0.615 \\
Morphotype x Cluster & 5 & 965.53 & 3.49 & 0.005 \\
Error & 228 & 276.79 & & \\
\hline
\end{tabular}

apparent seasonal pattern was observed. Nonetheless, there were conspicuous inter-annual differences in macroinvertebrate abundance since values of this attribute were higher for samples collected during summer 1996 (125.83 \pm 42.54 ind. per grab) than for summer $1997(65.33 \pm 18.80$ ind. per grab). A similar trend was observed for autumn 1996 (89.17 \pm 37.60 ind. per grab) and autumn 1997 (47.83 \pm 16.92 ind. per grab), and for winter 1997 and winter 1998 $(97.83 \pm 20.68$ and $64 \pm 26.12$ ind. per grab, respectively).

Macroinvertebrate assemblage composition differed significantly between sites and across seasons (two-way crossed ANOSIM, Global $\mathrm{R}$ for site $=0.653, p=0.1 \%$; Global $\mathrm{R}$ for season $=0.339, p=0.1 \%$ ) at the 0.05 level of significance. Crustaceans, particularly amphipods and decapods, were well represented at the two sites sampled; however, they were more abundant at Site 1 (59.33\%) than at Site $2(42.90 \%)$. Conversely, gastropod abundance was higher at Site $2(32.68 \%)$ than at Site $1(11.69 \%)$, in part because of the higher abundance of Bittium latreilli at Site 2 (see Table 7). Barleeia unifasciata and Calcinus tubularis were not recorded from Site 1, while Nereis rava was absent from Site 2. Species which occurred at a relatively low abundance at Site 2 (i.e., contributed to less than $1 \%$ of the total abundance at Site 2) but which had a higher abundance at Site 1, included: Leptochelia savignyi, Amphitoe ramondi, Echinocyamus pusillus and Gonilia calligypta (Table 7). Cheirocratus sundevallii contributed only $0.51 \%$ of the total abundance at Site 1 but $2.35 \%$ at Site 2. Flabellia petiolata ( $\%$ wet wt. $=45.9 \%$ ) was the dominant macroalga among the macroalgal assemblage recorded at the two sites sampled (Table 8). Codium bursa was absent from Site 2 but contributed to $50.8 \%$ of the total wet weight at Site 1, almost certainly due to its large size and high water content. Womersleyella setacea was present in $70.6 \%$ of the grab samples analysed and occurred more commonly at Site 1 than at Site 2 (present in $92.6 \%$ of grab samples at Site 1 vs. $41.7 \%$ grab samples at Site 2).

Temporal variation in epiphytic species abundance within and between sites was almost negligible; however, species abundance was higher at Site 1 than at Site 2 (Table 9), primarily due to higher density of Annectocyma 
Table 3 Mean, modal and median $\left(D_{50}\right)$ particle diameter $(\mu \mathrm{m})$, interquartile range $\left(\mathrm{D}_{75}-\mathrm{D}_{25}\right)$, sorting coefficient, skewness, kurtosis, percentage gravel, sand, and mud for each $2 \mathrm{~cm}$ layer in the core samples collected from Sites 1 and 2. Values are given in micrometers, values within the brackets are in phi

\begin{tabular}{|c|c|c|c|c|c|c|c|c|c|c|c|}
\hline & Mean & Mode & $\begin{array}{l}\text { Median } \\
\left(\mathrm{D}_{50}\right)\end{array}$ & $\begin{array}{l}\mathrm{IQR} \\
\left(\mathrm{D}_{75}-\mathrm{D}_{25}\right)\end{array}$ & $\begin{array}{l}\text { Sorting } \\
\text { coefficient }\end{array}$ & Skewness & Kurtosis & $\%$ Gravel & $\%$ Sand & $\%$ Mud & $\begin{array}{l}\text { Sediment } \\
\text { Textural group }\end{array}$ \\
\hline \multicolumn{12}{|l|}{ Site 1} \\
\hline $0-2 \mathrm{~cm}$ & $\begin{array}{r}1,721.5 \\
(-0.78)\end{array}$ & $\begin{array}{r}1,500.0 \\
(-0.5)\end{array}$ & $\begin{array}{r}1,585.5 \\
(-0.67)\end{array}$ & $\begin{array}{c}2,992.6 \\
(2.31)\end{array}$ & $2.63(1.40)$ & -0.25 & 0.60 & 40.8 & 58.8 & 0.4 & Sandy gravel \\
\hline $2-4 \mathrm{~cm}$ & $\begin{array}{c}1,133.8 \\
(-0.18)\end{array}$ & $\begin{array}{r}1,500.0 \\
(-0.5)\end{array}$ & $\begin{array}{c}1,164.8 \\
(-0.22)\end{array}$ & $\begin{array}{c}1,718.6 \\
(2.04)\end{array}$ & $2.94(1.56)$ & -0.03 & 1.03 & 27.8 & 71.4 & 0.8 & Gravelly sand \\
\hline $4-6 \mathrm{~cm}$ & $\begin{array}{c}989.6 \\
(0.02)\end{array}$ & $\begin{array}{r}1,500.0 \\
(-0.5)\end{array}$ & $\begin{array}{c}1,020.4 \\
(-0.03)\end{array}$ & $\begin{array}{r}1,348.0 \\
(1.87)\end{array}$ & $2.91(1.54)$ & -0.01 & 1.15 & 21.7 & 77.3 & 1.0 & Gravelly sand \\
\hline $6-8 \mathrm{~cm}$ & $\begin{array}{r}1,073.9 \\
(-0.10)\end{array}$ & $\begin{array}{c}1,500.0 \\
(-0.5)\end{array}$ & $\begin{array}{c}1,035.1 \\
(-0.05)\end{array}$ & $\begin{array}{c}1,897.1 \\
(2.35)\end{array}$ & $3.25(1.70)$ & 0.04 & 0.96 & 28.1 & 71.0 & 0.9 & Gravelly sand \\
\hline $8-10 \mathrm{~cm}$ & $\begin{array}{c}1,158.1 \\
(-0.21)\end{array}$ & $\begin{array}{r}1,500.0 \\
(-0.5)\end{array}$ & $\begin{array}{c}1,276.1 \\
(-0.35)\end{array}$ & $\begin{array}{r}2,148.1 \\
(2.34)\end{array}$ & $3.17(1.66)$ & -0.13 & 0.94 & 33.5 & 65.3 & 1.2 & Sandy gravel \\
\hline $10-12 \mathrm{~cm}$ & $\begin{array}{c}1,042.8 \\
(-0.06)\end{array}$ & $\begin{array}{r}1,500.0 \\
(-0.5)\end{array}$ & $\begin{array}{c}1,155.9 \\
(-0.21)\end{array}$ & $\begin{array}{r}1,608.1 \\
(2.05)\end{array}$ & $3.06(1.62)$ & -0.14 & 1.07 & 26.2 & 72.8 & 1.0 & Gravelly sand \\
\hline $12-14 \mathrm{~cm}$ & $\begin{array}{l}891.5 \\
(0.17)\end{array}$ & $\begin{array}{r}1,500.0 \\
(-0.5)\end{array}$ & $\begin{array}{l}965.2 \\
(0.05)\end{array}$ & $\begin{array}{r}1,220.2 \\
(1.81)\end{array}$ & $2.60(1.38)$ & -0.12 & 1.04 & 17.9 & 81.7 & 0.4 & Gravelly sand \\
\hline \multicolumn{12}{|l|}{ Site 2} \\
\hline $0-2 \mathrm{~cm}$ & $\begin{array}{c}1,924.5 \\
(-0.95)\end{array}$ & $\begin{array}{r}1,500.0 \\
(-0.5)\end{array}$ & $\begin{array}{l}1,753.8 \\
(-0.81)\end{array}$ & $\begin{array}{r}2,365.5 \\
(1.67)\end{array}$ & $2.30(1.20)$ & -0.20 & 0.84 & 43.1 & 56.8 & 0.1 & Sandy gravel \\
\hline $2-4 \mathrm{~cm}$ & $\begin{array}{r}1,257.2 \\
(-0.33)\end{array}$ & $\begin{array}{c}1,500.0 \\
(-0.5)\end{array}$ & $\begin{array}{r}1,291.9 \\
(-0.37)\end{array}$ & $\begin{array}{r}1,122.2 \\
(1.28)\end{array}$ & $2.09(1.06)$ & -0.09 & 1.16 & 21.9 & 77.8 & 0.3 & Gravelly sand \\
\hline $4-6 \mathrm{~cm}$ & $\begin{array}{r}1,080.3 \\
(-0.11)\end{array}$ & $\begin{array}{r}1,500.0 \\
(-0.5)\end{array}$ & $\begin{array}{r}1,141.0 \\
(-0.19)\end{array}$ & $\begin{array}{c}1,070.8 \\
(1.38)\end{array}$ & $2.06(1.05)$ & -0.12 & 1.10 & 16.5 & 83.0 & 0.5 & Gravelly sand \\
\hline $6-8 \mathrm{~cm}$ & $\begin{array}{l}848.8 \\
(2.47)\end{array}$ & $\begin{array}{r}1,500.0 \\
(-0.5)\end{array}$ & $\begin{array}{l}893.2 \\
(0.16)\end{array}$ & $\begin{array}{r}1121.7 \\
(1.72)\end{array}$ & $2.47(1.31)$ & -0.07 & 1.06 & 15.7 & 83.4 & 0.9 & Gravelly sand \\
\hline $8-10 \mathrm{~cm}$ & $\begin{array}{l}912.8 \\
(0.13)\end{array}$ & $\begin{array}{r}1,500.0 \\
(-0.5)\end{array}$ & $\begin{array}{c}1,004.2 \\
(-0.01)\end{array}$ & $\begin{array}{r}1,023.4 \\
(1.50)\end{array}$ & $2.23(1.16)$ & -0.19 & 1.09 & 12.2 & 87.2 & 0.6 & Gravelly sand \\
\hline $10-12 \mathrm{~cm}$ & $\begin{array}{r}1,172.0 \\
(-0.23)\end{array}$ & $\begin{array}{r}1,500.0 \\
(-0.5)\end{array}$ & $\begin{array}{r}1,259.2 \\
(-0.33)\end{array}$ & $\begin{array}{c}1,215.6 \\
(1.46)\end{array}$ & $2.19(1.13)$ & -0.17 & 1.06 & 22.2 & 77.5 & 0.3 & Gravelly sand \\
\hline $12-14 \mathrm{~cm}$ & $\begin{array}{c}987.5 \\
(0.02)\end{array}$ & $\begin{array}{r}1,500.0 \\
(-0.5)\end{array}$ & $\begin{array}{c}1,098.5 \\
(-0.14)\end{array}$ & $\begin{array}{r}1,166.0 \\
(1.60)\end{array}$ & $2.29(1.19)$ & -0.18 & 1.02 & 17.4 & 82.3 & 0.4 & Gravely sand \\
\hline
\end{tabular}

sp. at Site $1\left(3.47 \pm 2.45\right.$ ind. per $100 \mathrm{~cm}^{2}$ at Site 1 vs. $0.05 \pm$ 0.06 ind. per $100 \mathrm{~cm}^{2}$ at Site 2), and of Mollia patellaria at Site $2\left(0.06 \pm 0.16\right.$ ind. per $100 \mathrm{~cm}^{2}$ at Site 1 vs. $2.29 \pm 1.73$ ind. per $100 \mathrm{~cm}^{2}$ at Site 2). Abundance was significantly

Table 4 Maximum length, weight and volume of rhodoliths from six grab samples collected from Sites 1 and 2 during July 1996. Mean length, mean weight, and mean volume per rhodolith were calculated from measurements made for 50 randomly chosen rhodoliths from each of the 6 grab samples collected from Sites 1 and 2 (i.e., $n=300$ )

\begin{tabular}{llll}
\hline & & Site 1 & Site 2 \\
\hline Length $(\mathrm{mm})$ & Maximum & 39.5 & 48.60 \\
& Mean $\pm \mathrm{SD}$ & $14.12 \pm 4.62$ & $15.71 \pm 6.12$ \\
Weight $(\mathrm{g})$ & Maximum & 16.6 & 39 \\
& Mean $\pm \mathrm{SD}$ & $0.33 \pm 0.60$ & $1.01 \pm 2.01$ \\
Volume $\left(\mathrm{cm}^{3}\right)$ & Maximum & 7.7 & 23 \\
& Mean $\pm \mathrm{SD}$ & $0.16(/)$ & $0.49(/)$ \\
\hline
\end{tabular}

Table 5 Two-way ANOVA results for (a) number of species (S) and (b) total abundance of species between sites and among sampling seasons. Encrusting animal forms including bryozoans, sponges and hydroids were excluded from analysis of number of species, while encrusting animal forms and algae were excluded from analysis of abundance

\begin{tabular}{|c|c|c|c|c|}
\hline & $d f$ & MS & $F$ & $p$ value \\
\hline \multicolumn{5}{|c|}{ (a) Number of species (S) } \\
\hline Site & 1 & 697.69 & 9.58 & 0.004 \\
\hline Season & 7 & 159.83 & 2.19 & 0.061 \\
\hline Site $\mathrm{x}$ season & 7 & 78.59 & 1.08 & 0.399 \\
\hline Error & 32 & 72.85 & & \\
\hline \multicolumn{5}{|c|}{ (b) Total abundance (individuals per grab) } \\
\hline Site & 1 & $2,929.69$ & 4.44 & 0.043 \\
\hline Season & 7 & $4,900.28$ & 7.42 & $<0.001$ \\
\hline Site $\mathrm{x}$ season & 7 & 440.07 & 0.67 & 0.70 \\
\hline Error & 32 & 660.54 & & \\
\hline
\end{tabular}


Table 6 Mean values ( \pm SD) of (a) number of species, (b) abundance, and (c) wet weight for biota recorded from the two sites. Number of species and abundance excludes encrusting animal forms (Bryozoa, Porifera, hydroids). Wet weight values do not include all the recorded algal species (see Material and methods)

\begin{tabular}{llll}
\hline & Site 1 & Site 2 & Overall \\
\hline (a) Number of species & & & \\
Macroinvertebrates & $23.33 \pm 9.59$ & $21.83 \pm 8.42$ & $22.58 \pm 8.96$ \\
Macroalgae & $14.63 \pm 5.67$ & $8.5 \pm 4.67$ & $11.56 \pm 6.00$ \\
Biota & $37.96 \pm 8.56$ & $30.33 \pm 10.03$ & $34.15 \pm 10.00$
\end{tabular}

(b) Abundance (individuals per grab)

Macroinvertebrates $\quad 65.79 \pm 34.12 \quad 81.42 \pm 37.15 \quad 73.60 \pm 36.16$

(c) Wet weight (g per grab)

Macroalgae

$7.00 \pm 4.70$

$11.36 \pm 12.76$

correlated with rhodolith size, surface area and sphericity (Pearson product-moment correlation coefficient for size: $r=0.47, p<0.01$; for surface area: $r=0.60, p<0.01$; for sphericity: $r=0.20, p<0.05)$ and differed also with rhodolith shape. Whereas abundance of epiphytic fauna was highest for laminar rhodoliths ( $\%$ abundance of individuals on morph $\mathrm{B}=34$, morph $\mathrm{C}=13$, morph $\mathrm{F}=9$ ), epifaunal species richness was higher on closely branched

Table 7 Species that contributed to at least $80 \%$ of the total animal abundance. The $\%$ abundance contribution of species to the total abundance at each site ( $\%$ abundance $)$ and to their respective taxa
$15.71 \pm 16.46$

rhodoliths (number of species on morph $\mathrm{B}=35$, morph $\mathrm{C}=$ 29, morph $\mathrm{F}=41$ ).

\section{Trophic group analysis}

Predators were the dominant trophic group in terms of species richness $(24.1 \%)$, but deposit feeders were by far the most abundant trophic group in terms of number of individuals (42.4\%) (Table 10). Multifunctional feeders were represented by only 12 species, but contributed to $16.8 \%$ of the total abundance. Conversely, grazers (microand macrograzers) constituted $14.4 \%$ of the non-epiphytic species diversity, but only $8.2 \%$ of the total abundance (Table 10). The most abundant predatory species were Lysidice ninetta and Eunice vittata, which contributed to $52.2 \%$ of the predators at Site 1 and $70.5 \%$ at Site 2 . Bittium latreilli was dominant amongst the deposit feeders, with a greater contribution at Site $2(45.1 \%)$ than at Site 1 (21.0\%). The deposit feeder Leptochelia savignyi (19.9\%) was replaced by its trophic equivalent Barleeia unifasciata $(18.5 \%)$ at Site 2. Suspension feeders were represented by 28 species with a dominance of Pteromeris minuta, Turritella turbona and Argyrotheca cuneata, however, this trophic group contributed to just $5.5 \%$ of the total

(\% ab. taxa) (including Bivalvia - $B$, Gastropoda - $G$, Crustacea - $C$, Polychaeta - $P$, Echinodermata - $E$ and Sipuncula $-S$ ) is given

\begin{tabular}{|c|c|c|c|c|c|}
\hline Site 1 & $\%$ Abundance & $\%$ ab. taxa. & Site 2 & $\%$ Abundance & $\%$ ab. taxa. \\
\hline Bittium latreilli $(\mathrm{G})$ & 11.69 & 64.49 & Bittium latreilli $(\mathrm{G})$ & 23.16 & 56.68 \\
\hline Cestopagurus timidus (C) & 11.36 & 16.77 & Cestopagurus timidus (C) & 14.09 & 28.28 \\
\hline Leptochelia savignyi (C) & 11.10 & 16.40 & Barleeia unifasciata $(\mathrm{G})$ & 9.52 & 23.29 \\
\hline Lysianassa costae $(\mathrm{C})$ & 7.88 & 11.64 & Lysidice ninetta $(\mathrm{P})$ & 9.07 & 50.18 \\
\hline Amphitoe ramondi $(\mathrm{C})$ & 7.37 & 10.89 & Eunice vittata $(\mathrm{P})$ & 5.33 & 29.47 \\
\hline Galathea intermedia (C) & 7.29 & 10.76 & Lysianassa costae (C) & 4.31 & 8.66 \\
\hline Maera grossimana $(\mathrm{C})$ & 5.93 & 8.76 & Ceradocus semiserratus (C) & 4.06 & 8.15 \\
\hline Echinocyamus pusillus (E) & 5.51 & 65.66 & Maera grossimana $(\mathrm{C})$ & 4.00 & 8.03 \\
\hline Lysidice ninetta $(\mathrm{P})$ & 5.08 & 21.72 & Calcinus tubularis (C) & 3.55 & 50.18 \\
\hline Eunice vittata $(\mathrm{P})$ & 4.92 & 22.47 & Galathea intermedia (C) & 3.05 & 28.28 \\
\hline Nereis rava $(\mathrm{P})$ & 3.47 & 15.36 & Athanas nitescens $(\mathrm{C})$ & 2.79 & 5.61 \\
\hline Gonilia calliglypta (B) & 3.14 & 23.72 & Aspidosiphon (A.) muelleri (S) & 2.73 & 100 \\
\hline Ceradocus semiserratus (C) & 2.80 & 4.13 & Cheirocratus sundevallii (C) & 2.35 & 4.71 \\
\hline Anapagurus breviaculeatus (C) & 2.63 & 3.88 & Genocidaris maculata (E) & 2.35 & 67.27 \\
\hline Genocidaris maculata $(\mathrm{E})$ & 2.46 & 29.29 & Anapagus breviaculeatus (C) & 2.16 & 4.33 \\
\hline Pteromeris minuta $(\mathrm{B})$ & 2.12 & 16.03 & Pteromeris minuta $(\mathrm{B})$ & 1.84 & 36.25 \\
\hline Socarnes filicornis $(\mathrm{C})$ & 1.27 & 1.88 & Socarnes filicornis (C) & 1.65 & 3.31 \\
\hline Athanas nitescens $(\mathrm{C})$ & 1.19 & 1.75 & Echinocyamus pusillus (E) & 0.89 & 25.45 \\
\hline Aspidosiphon (A.) muelleri (S) & 0.85 & 90.90 & Gonilia calliglypta (B) & 0.76 & 15 \\
\hline Cheirocratus sundevallii (C) & 0.51 & 0.75 & Amphitoe ramondi $(\mathrm{C})$ & 0.51 & 1.02 \\
\hline Barleeia unifasciata $(\mathrm{G})$ & 0 & 0 & Leptochelia savignyi (C) & 0.38 & 0.76 \\
\hline Calcinus tubularis (C) & 0 & 0 & Nereis rava $(\mathrm{P})$ & 0 & 0 \\
\hline
\end{tabular}


Table 8 Percentage wet weight of algal species with a contribution greater than or equal to $0.1 \%$ of the total wet weight

\begin{tabular}{llll}
\hline Site 1 & \% Wet weight & Site 2 & \% Wet weight \\
\hline Codium bursa & 50.79 & Flabellia petiolata & 72.34 \\
Flabellia petiolata & 34.18 & Cystoseira corniculata & 10.60 \\
Cystoseira corniculata & 10.18 & Dictyota dichotoma & 10.36 \\
Vidalia volubilis & 2.69 & Cystoseira sp. & 5.58 \\
Rytiphloea tinctoria & 0.78 & Vidalia volubilis & 0.41 \\
Gracilaria dura & 0.22 & Osmundea pelagosae & 0.21 \\
Dictyota dichotoma & 0.20 & Gracilaria dura & 0.12 \\
Halimeda tuna & 0.20 & & \\
Laurencia sp. & 0.19 & & \\
Cystoseira sp. & 0.11 & & \\
Osmundea pelagosae & 0.10 & & \\
\hline
\end{tabular}

abundance. Cestopagurus timidus was the dominant multifunctional feeder, contributing to $68.4 \%$ and $57.8 \%$ to this trophic group at Sites 1 and 2, respectively. Dexamine spinosa and Mitrella scripta were the major macrograzers, whereas Echinocyamus pusillus and Genocidaris maculata were the dominant micrograzers.

\section{Discussion}

Characterization of the maerl bed

Throughout 1996-1998, the water above the maerl bed had low amounts of suspended matter (maximum recorded value $=2.92 \mathrm{mg}^{-1}$ ) and consequently was very transparent (maximum recorded Secchi depth=31.9 $\mathrm{m}$ ). The high degree of light penetration can therefore explain the common occurrence of live coralline algae at a water depth of 51-90 m, which far exceeds most other maerl beds in the NE Atlantic that typically occur from low in the intertidal to a depth of ca. $30 \mathrm{~m}$ (Birkett et al. 1998). The higher occurrence of nucleated rhodoliths suggests in situ settlement and development of propagules, rather than development elsewhere (e.g., in a 'rhodolith factory'; Freiwald 1995) and transport of broken pieces to the maerl bed. The overall coarse nature of the non-biogenic sediment at the sampling stations indicates the presence of moderate water movement which winnows away the finer particles from the surface layers of the sediment or prevents their deposition. Storm-induced bottom currents are an important source of bottom disturbance for rhodolith movement (Bosellini and Ginsburg 1971; Di Geronimo and Giaccone 1994; Harris et al. 1996), and although storms (defined as gale force 10 on the Beaufort scale) are seldom experienced in the Maltese Islands, gusts exceeding 34 knots may occur periodically, mostly between October and March. Although water currents along the NE coast of Malta are relatively weak, only reaching a maximum speed of $0.3 \mathrm{~ms}^{-1}$ and a mean speed of $0.13 \mathrm{~ms}^{-1}$ (measured $6.3 \mathrm{~m}$ above the seabed in water $35 \mathrm{~m}$ deep off the northeastern coast of Malta) (Drago 1995), currents may interact with local topographic features to produce complex flows, for example near headlands (Geyer and Signell 1990; Wolanski and Hamner 1988), bays, boulders (Cusson and Bourget 1997; Guichard and Bourget 1998), and reefs (Black and Moran 1991; Wolanski and Hamner 1988). The observed coarser nature of the nonbiogenic sediment for stations closer to 'is-Sikka 1-Bajda' shoal (Cluster 1 stations, Site 2) suggest that these may be under the influence of a different hydrodynamic regime than those further away (Cluster 2 stations, Site 1), potentially offering more favorable conditions for rhodolith growth as higher percentage mass of live rhodoliths were
Table 9 Total number of species and mean abundance $( \pm \mathrm{SD})$ (individuals per $100 \mathrm{~cm}^{2}$ of rhodolith surface) for each of the six epiphytic faunal taxa recorded growing on rhodoliths

\begin{tabular}{llllll}
\hline & \multicolumn{2}{l}{ Number of species } & & \multicolumn{2}{l}{ Abundance (individuals per $100 \mathrm{~cm}^{2}$ of rhodolith surface) } \\
\cline { 2 - 3 } \cline { 5 - 6 } & Site 1 & Site 2 & & Site 1 & Site 2 \\
\hline Bryozoa & 13 & 15 & & $13.97 \pm 4.9$ & $6.91 \pm 1.68$ \\
Porifera & 12 & 14 & & $3.64 \pm 2.40$ & $2.94 \pm 1.47$ \\
Annelida & 7 & 9 & & $16.23 \pm 8.92$ & $5.44 \pm 4.09$ \\
Foraminifera & 2 & 2 & & $6.60 \pm 2.59$ & $0.71 \pm 0.42$ \\
Cnidaria & 2 & 2 & & $2.68 \pm 1.08$ & $0.45 \pm 0.27$ \\
Mollusca & 1 & 1 & & $0.37 \pm 0.42$ & $0.10 \pm 0.24$ \\
\hline
\end{tabular}


Table 10 Raw values and percentage number of individuals in each trophic group. Data includes animal species collected from both sites

\begin{tabular}{|c|c|c|c|c|}
\hline \multirow[t]{2}{*}{ Trophic Group } & \multicolumn{2}{|c|}{ Number of species } & \multicolumn{2}{|c|}{ Number of individuals } \\
\hline & Raw & Percentage & Raw & Percentage \\
\hline Deposit feeders & 44 & 22.56 & 1465 & 42.37 \\
\hline Macrograzers & 16 & 8.21 & 96 & 2.78 \\
\hline Micrograzers & 12 & 6.15 & 186 & 5.38 \\
\hline Multifunctional feeders & 12 & 6.15 & 580 & 16.77 \\
\hline Predators & 47 & 24.10 & 547 & 15.82 \\
\hline Scavengers & 6 & 3.08 & 214 & 6.19 \\
\hline Suspension feeders & 28 & 14.36 & 191 & 5.52 \\
\hline Suspension/deposit feeders & 11 & 5.64 & 126 & 3.64 \\
\hline Predator/scavenger & 3 & 1.54 & 12 & 0.35 \\
\hline Others & 7 & 3.59 & 21 & 0.61 \\
\hline Unknown & 8 & 4.10 & 20 & 0.58 \\
\hline
\end{tabular}

recorded at stations in the vicinity of the shoal (\% mass of rhodoliths at Cluster 1 stations $=26.35 \pm 9.81 \%$, Cluster 2 stations $=7.22 \pm 5.76 \%$, Site $1=5.82 \%$, Site $2=18.35 \%$ ). Different intensities of water motion have been shown to influence rhodolith shape, branching pattern and sphericity (Bosellini and Ginsburg 1971; Prager and Ginsburg 1989; Steneck 1986; Steller and Foster 1995). Closely branched rhodoliths (morph F) were more common at stations closer to the shoal, while open branched rhodoliths (morph E) had a higher percentage mass at stations further away from the shoal (Fig. 4), similarly indicating an increased bottom instability due to higher energy environment in the vicinity of the shoal. Our results are in good agreement with observations by Di Geronimo and Giaccone (1994) and Steneck (1986), which suggest that spherical, denselybranched rhodoliths are typical of high water movement regimes, while open-branched rhodoliths are found in more stable environments. The scarcity of laminar forms such as morph B may be accounted for by the fact that laminar forms generally form under relatively calm conditions, on sediments that have a substantial high mud content. As the whole study area is poor in muddy sediments $(<2 \%)$, laminar morphotypes are not expected to be abundant.

\section{3-D structure of the maerl bed}

Live rhodoliths formed ca. $2 \mathrm{~cm}$ stratum overlying a moderately to poorly sorted, gravelly sand. The underlying sediment layer comprised of an upper layer of ca. $7 \mathrm{~cm}$ of loosely packed dead rhodolith thalli with some coarse sand and a lower layer of hard-packed rhodolith debris and medium to fine sand. The loosely packed upper layer of dead rhodolith thalli suggests a good circulation of nutrients and oxygen, which coupled with the heterogeneous structure of rhodoliths, increases the number of niches available for benthic organisms that utilize the vertical dimension of the maerl bed (Hall-Spencer 1998; Keegan 1974). Burial of rhodoliths below the porous upper layer may be due to considerable water movement or bioturbation. Deposit feeders such as Leptochelia savingyi, Amphitoe ramondi, Galathea intermedia, Maera grossimana, and Nereis rava that were recorded during this study, may contribute to rhodolith mixing in the surface sediment while feeding on other benthic organisms. Bottom-foraging fish such as Mullus surmuletus and Pagellus erythrinus (known to occur in large populations on the maerl ground studied) and large deep-burrowing animals (such as large irregular echinoids whose fragments were recovered from Maltese maerl samples) are also expected to contribute to bioturbation (e.g., Fischer et al. $1987 \mathrm{a}, \mathrm{b}$ ); however, this could not be confirmed during the present study given that the sampling protocol used was appropriate for collecting macroinvertebrates but not the megafauna and fishes.

\section{Associated biota}

The maerl bed biotic assemblage was equally rich in algae and fauna typical of both hard and soft substrata. Rhodoliths, therefore, appear to extend the distribution of species requiring hard substrata for attachment, that would otherwise be absent from soft substrata. The faunal assemblage included (1) burrowing and interstitial forms that utilize the sediment underlying the rhodoliths and the interstices between the rhodolith thalli (polychaetes, irregular echinoids, bivalves and amphipods); (2) sessile epifaunal organisms that utilise the rhodoliths and the stabilised upper layer of sediment (tube-dwelling polychaetes and crustaceans, byssate bivalves, ascidians, sponges and bryozoans); and (3) vagile epifauna (decapods and gastropods). 
Estimates of species richness and abundance are sampledesign dependent, and thus comparisons of species diversity between studies is difficult. Nonetheless, as has been recorded in studies of tropical and temperate rhodolith beds (e.g., Bordehore et al. 2003, Foster et al. 2007; Grall et al. 2006; Hinojosa-Arango and Riosmena-Rodríguez 2004; Steller et al. 2003), our results show that annelids, crustaceans, and molluscs are the dominant faunal groups both in terms of abundance and species richness. Within the rhodolith-associating Crustacea, the amphipods were the most species-rich and abundant group, followed by the decapods (Table 7). De Grave (1999) documented 48 species of amphipods, which were found to constitute $95.4 \%$ of the total abundance of the crustacean assemblage collected from the maerl beds at Mannin Bay, Ireland. On the other hand, Barberá et al. (1999) stated that amphipods represented only $4.6 \%$ of the maerl fauna in Alicante (Spain), and these maerl beds were dominated by polychaetes and gastropods. Echinoderms did not constitute a dominant group among the macroinvertebrates collected in the present study (Table 7); however, a recent video survey of the Maltese maerl beds showed the crinoid Antedon mediterranea, the echinoids Centrostephanus longispinus and Stylocidaris affinis, and the asteroids Echinaster sepositus and Astropecten sp. to be common megaepifaunal species (unpublished data).

The majority of animal species recorded from the maerl bed also occur in other infralittoral and circalittoral habitats (De Grave 1999; Pérès 1967). For example, some $42 \%$ of the bivalves, $49 \%$ of the gastropods, and $44 \%$ of the decapod species recorded in the present study have also been recorded by Howege (1998) and Borg and Schembri (2000) from seagrass (Posidonia oceanica) meadows. Similarly, gravel-associated species such as the decapods Liocarcinus zariqueiyi and Parthenope expansa, the ascidian Rhopalaea neapolitana, and the echinoid Echinocyamus pusillus were also recorded from this maerl bed. This suggests that maerl-associated biota do not depend on the live rhodoliths per se but on the rhodolith-derived sediment and on the complex architecture arising from the gross morphology of the rhodoliths and their interlinking (De Grave et al. 2000; Pérès 1967; Rowe et al. 1990).

Flabellia petiolata and the non-indigenous filamentous rhodophyte Womersleyella setacea, were observed to grow profusely on rhodoliths, binding the rhodoliths into a 'pseudohard' surface. Although this stabilized surface layer provides an additional substratum for settlement of foliose macroalgae on rhodoliths, it may deprive settlement and attachment of interstitial species, reduce the amount of photosynthetically active radiation reaching the photosynthetic tissues of the rhodolith-forming algae, and prevent rhodoliths from turning-a requirement for their survival.
Many studies have consistently verified the importance of rhodoliths to the associated species (review in AmadoFilho et al. 2007; De O Figueiredo et al. 2007; Foster et al. 2007; Steller et al. 2003). Our observations suggest that rhodolith surface area and shape play a role in maintaining a diversity of rhodolith-associated epiphytic fauna; a higher number of epiphytic animal species were recorded on closely branched rhodoliths (morph F), which offer a higher structural complexity and a larger number of microhabitats for epiphytic fauna than spherical (morph C) rhodoliths.

The observed spatial heterogeneity in species composition may be attributable to topographical heterogeneity, which has been shown to influence the assemblage structure by modifying the local hydrodynamic regime (Eckman 1983), food availability (Abelson and Loya 1995), rhodolith morphology (Bosence 1976; Steller and Foster 1995), predation intensity (Menge et al. 1985), competition (Menge 1976), larval dispersal, and recruitment (Archambault and Bourget 1999). For example, the higher abundance of amphipods at Site 1 could be related to the higher abundance of fleshy macroalgae at Site 1, which provide amphipods with a source of detritus (BIOMAERL Team 1999) and protection from predators. Codium bursa represented $50 \%$ of the total algal wet weight at Site 1, but was absent from Site 2 (Table 8). This species is a very slow growing alga (Vidondo and Duarte 1995) with weak attachment, and is easily dislodged by water movement, hence its absence from Site 2 might further suggest a higher degree of bottom instability at this site. Furthermore, the abundance of epiphytic biota was markedly higher at Site 1 than Site 2 (Table 9), similarly indicative of increased sediment movement at Site 2, which prevents attachment and growth of epiphytic biota due to abrasion. Bottom trawling does not appear to contribute to substantial physical disturbance at the maerl bed studied (Borg et al. 1999), probably because fishing, being illegal within 3 nautical miles off the Maltese coast, only occurs sporadically. It is thus likely that the observed spatial differences in species assemblage composition are due to higher physical disturbance at Site 2, owing to its vicinity to 'isSikka 1-Bajda' shoal, as is suggested from sediment granulometry and rhodolith structural characteristics.

Trophic group analysis

The relatively low contribution of grazers (micro- and macrograzers) to the total abundance (Table 10) suggests that most of the primary production present in the area is not consumed in situ by herbivores but rather enters the food web via the detrital pathway. Deposit feeders were indeed the most species-diverse after predators, as well as the most abundant group. The coexistence of a noticeably large number of deposit feeding species can be attributed to 
the heterogeneity of the maerl bed, and might suggest niche partitioning of the deposit feeding resource axis. Rowe et al. (1990) have also recorded deposit feeders to be dominant on Irish maerl beds. On the other hand, De Grave (1999) and Grall and Glémarec (1997) found a prevalence of predators, followed by scavengers and then deposit feeders, on maerl beds in Brittany and Ireland (Mannin Bay), respectively. The relatively high number of predatory species on the maerl bed can explain the coexistence of a large number of prey species in the same trophic group, since predators may maintain the level of their prey below the threshold level of competitive exclusion (Grall and Glémarec 1997).

\section{Conclusion}

Maerl beds have long been recognized as habitats that support a particularly high diversity of flora and fauna, and are considered analagous to kelp forests and seagrass beds in this respect. Although few of the species found in maerl biotopes are confined solely to these habitats, it is the total species assemblage within the maerl biotope that makes it unique. The present study shows maerl beds present along the NE coast of the Maltese Islands to be 'biodiversity hotspots', in terms of macroalgae, infauna and macroepifaunal species. The potential importance of maerl as a habitat for the juvenile stages of demersal and pelagic species and the high secondary production they support is recognised by local fishers, who risk punitive action by fishing illegally over these beds. Despite their important roles as productive marine ecosystems that support a high biodiversity (Kamenos et al. 2004b; Martin et al. 2007), and notwithstanding their status as a non-renewable resource, rhodoliths have been threatened by several types of human activity, including large-scale commercial extraction, alteration of water quality by discharges, and use of heavy demersal fishing gear, the effects of which might be irreversible over timescales relevant to humans. Maerl beds are now receiving local and international protection and some maerl-forming species such as Lithothamnion corallioides and Phymatolithon calcareum are both included in Annex V of the EC 'Habitats Directive' 1992. It is widely recognised that to manage specific habitats and species effectively, there needs to be a relatively clear understanding of their present known distribution, the underpinning biology and ecology, and their sensitivity to natural and anthropogenic disturbance. The present study contributes to the knowledge of the physical, structural, taxonomical and functional characteristics of the maerl bed present along the NE coast of the Maltese Islands, which is a necessity for setting realistic guidance for effective management and monitoring.
Acknowledgments Part of this research was undertaken in the framework of the BIOMAERL project with support from the European Commission's Marine Science and Technology Programme (MAST III) under contract MAS3-CT95-0020. Maltese participation in the BIOMAERL project was made possible through grants from the University of Malta, the Malta Council for Science and Technology, and the Ministry of Education of the Government of Malta, for which we are grateful. We thank Prof P.G.Moore (University Marine Biological Station, Millport and coordinator of the BIOMAERL project) and Dr J. Hall-Spencer (University of Plymouth) for their help and interest. We are also grateful to two anonymous referees whose comments on an earlier draft of this paper greatly improved it. The work described in this paper was carried out in full conformity with the laws of Malta. The authors declare that they have no conflict of interest.

\section{References}

Abelson A, Loya Y (1995) Cross-scale patterns of particulate food acquisition in marine benthic environments. Am Nat 145:848-854

Agnesi S, Annunziatellis A, Casese ML, Di Nora T, La Mesa G, Mo G, Pergent-Martini C, Tunesi L (2009) Analysis on the coralligenous assemblages in the Mediterranean Sea: a review of the current state of knowledge in support of future investigations. In: Pergnt-Martini C, Brichet M (eds) UNEP-MAPRAC/SPA (2009) Proceedings of the 1st Mediterranean symposium on the conservation of the coralligeous and other calcareous bio-concretions (Tabarka, 15-16 January 2009). RAC/SPA publication, Tunis

Airoldi L, Beck MW (2007) Loss, status and trends for coastal marine habitats of Europe. Oceanogr Mar Biol Annu Rev 45:345-405

Amado-Filho GM, Maneveldt G, Manso RCC et al (2007) Structure of rhodolith beds from 4 to 55 meters deep along the southern coast of Espírito Santo State, Brazil. Cienc Mar 33:399-410

Archambault P, Bourget E (1999) Influence of shoreline configuration on spatial variation of meroplanktonic larvae, recruitment and diversity of benthic subtidal communities. J Exp Mar Biol Ecol 238:161-184

Ballesteros E (2006) Mediterranean coralligenous assemblages: a synthesis of present knowledge. Oceanogr Mar Biol Annu Rev 44:123-195

Barberá C, Valle C, Bordehore C, Patiño JL, Martínez MC, Sánchez-Jérez P, Ramos-Esplà AA (1999) Caracterización de los fondos de maërl y macrofauna asociada de la Reserva Marina de Tabarca (Alicante, SE Península Ibérica). In: BIOMAERL Team. Final Report (in 2 vols.), BIOMAERL project (Co-ordinator: P.G. Moore, University Marine Biological Station Millport, Scotland) EC Contract No. MAS3CT95-0020, pp 1-541, 542-973 + appendix

Barberá C, Bordehore C, Borg JA, Glemarec M, Grall J, Hall-Spencer J, De La Huz C, Lanfranco E, Lastra M, Moore PG, Mora J, Pita ME, Ramos-Espla AA, Rizzo M, Sanchez-Mata A, Seva A, Schembri PJ, Valle C (2003) Conservation and management of northeast Atlantic and Mediterranean maerl beds. Aquat Conserv Mar Freshw Ecosyst 13(S1):S65-S76

BIOMAERL Team (1998) Maerl grounds: habitats of high biodiversity in European seas. In: Third European Marine Science \& Technology Conference (Lisbon, 23-27 May 1998); Project Synopses, Vol. I: Marine Systems. European Commission DG 12 Science, Research and Development, Luxembourg; pp 169-178

BIOMAERL Team (1999) Final Report, BIOMAERL project (Coordinator: P.G. Moore, University Marine Biological Station Millport, Scotland) EC Contract No. MAS3-CT95-0020, (in 2 vols.) pp 1-541, 542-973 + appendix 
Birkett DA, Maggs CA, Dring MJ (1998) An overview of dynamic and sensitivity characteristics for conservation management of marine SACs, Vol 5, Maerl [UK Marine SACs Project] Scottish Association for Marine Science, Scotland, pp 116

Black KP, Moran PJ (1991) Influence of hydrodynamics on the passive dispersal and initial recruitment of larvae of Acanthaster planci (Echinodermata: Asteroidea) on the Great Barrier Reef. Mar Ecol Prog Ser 69:55-65

Blake C, Maggs CA (2003) Comparative growth rates and internal banding periodicity of maerl species (Corallinales, Rhodophyta) from northern Europe. Phycol 42:606-612

Blott SJ, Pye K (2001) GRADISTAT: a grain size distribution and statistics package for the analysis of unconsolidated sediment. Earth Surf Proc Land 26:1237-1248

Bordehore C, Ramos-Espla AA, Riosmena-Rodriduez R (2003) Comparative study of two maerl beds with different otter trawling history, southeast Iberian Peninsula. Aquat Conserv Mar Freshw Ecosyst 13:S43-S54

Borg JA, Schembri PJ (2000) Bathymetric distribution of decapods associated with a Posidonia oceanica meadow in Malta (Central Mediterranean). In: Von Vaupel Klein JC, Schram FR (eds) The biodiversity crisis and Crustacea. [Crustacean Issues 12]. A.A. Balkerna, Rotterdam, pp 119-130

Borg JA, Howege HM, Lanfranco E et al (1998) The macrobenthic species of the infralittoral to circalittoral transition zone off the northeastern coast of Malta (Central Mediterranean). Xjenza 3:16-24

Borg JA, Lanfranco E, Mifsud JR, Rizzo M, Schembri PJ (1999) Does fishing have an impact on Maltese maerl grounds? In: BIOMAERL team (1999) Final Report (in 2 vols), BIOMAERL project (Co-ordinator: P.G. Moore, University Marine Biological Station Millport, Scotland), EC Contract No. MAS3-CT95-0020, pp 1-541, 542-973 + appendix

Bosellini A, Ginsburg RN (1971) Form and internal structure of recent algal nodules (rhodolites) from Bermuda. J Geol 79:669-682

Bosence DWJ (1976) Ecological studies on two unattached coralline algae from western Ireland. Palaeontology 19:365-395

Bosence D, Wilson J (2003) Maerl growth, carbonate production rates and accumulation rates in the northeast Atlantic. Aquat Conserv Mar Freshw Ecosyst 13:S21-S31

Buchanan JB, Kain JM (1971) Measurement of the physical and chemical environment. In: Holme NA, McIntyre AD (eds) Methods for the study of marine benthos, 2nd edn. Blackwell, Oxford, pp 30-35

Clarke KR, Warwick RM (2001) Change in marine communities: An approach to statistical analysis and interpretation. Plymouth Marine Laboratory, UK

Cusson M, Bourget E (1997) Influence of topographical heterogeneity and spatial scales on the structure of the neighbouring intertidal endobenthic macrofaunal community. Mar Ecol Prog Ser 150:181-193

Day JH (1967) A monograph on the Polychaeta of Southern Africa, Part 1: Errantia; Part 2: Sedentaria. Trustees of the British Museum (Natural History) London, xvii + pp 878

De Grave S (1999) The influence of sedimentary heterogeneity on within maerl bed differences in infaunal crustacean community. Estuar Coast Shelf Sci 49:153-163

De Grave S, Fazakerley H, Kelly L, Guiry MD, Ryan M, Walshe J (2000) A study of selected maerl beds in Irish waters and their potential for sustainable extraction. [Marine Resources Series 10]. Marine Institute, Dublin

De O Figueiredo MA, Santos de Menezes K, Costa-Paiva EM et al (2007) Experimental evaluation of rhodoliths as living substrata for infauna at the Abrolhos Bank, Brazil. Cienc Mar 33:427-440

Di Geronimo R, Giaccone G (1994) Le alghe calcaree nel detritico costiero di Lampedusa (Isole Pelagie). Boll Acad Gioenia Sci Nat $27: 5-25$
Dimech M, Borg JA, Schembri PJ (2004) Report on a video survey of an offshore area off Zonqor Point (south-eastern coast of Malta), made in April 2004 as part of baseline ecological surveys in connection with the establishment of an 'aquaculture zone'. Report I Preliminary video characterization. [Survey commissioned by the Malta Environment and Planning Authority]. Msida, Malta: Malta University Services Ltd; pp 14 + Figs 1-4 + video [2 DVDs]

Drago AF (1995) Development of a capability in physical oceanography for the Maltese Islands, MPhil upgrading report, Dept. of Oceanography, University of Southampton, UK

Eckman JE (1983) Hydrodynamic processes affecting benthic recruitment. Limnol Oceanogr 22:241-257

Fischer W, Bauchot ML, Schneider M (eds) (1987a) Fisches FAO d'identification des espèces pour les besoins de la pêche (Révision 1). Mediterranée et mer Noire. Zone de pêche 37. Volume I. Végétaux et Invertébrés. Food and Agriculture Organisation of the United Nation (FAO), Rome, pp 760

Fischer W, Bauchot ML, Schneider M (eds) (1987b) Fisches FAO d'identification des espèces pour les besoins de la pêche (Révision 1). Mediterranée et mer Noire. Zone de pêche 37. Volume II. Vertébrés. Food and Agriculture Organisation of the United Nation (FAO), Rome, pp 761-1530

Foster MS (2001) Rhodoliths: between rocks and soft places. J Phycol 37:659-667

Foster MS, McConnico LM, Lundsten L et al (2007) Diversity and natural history of a Lithothamnion muelleri-Sargassum horridum community in the Gulf of California. Cienc Mar 33:367-384

Freiwald A (1995) Sedimentological and biological aspects in the formation of branched rhodoliths in northern Norway. Beitr Paläontol 20:7-19

Freiwald A, Henrich R (1994) Reefal coralline algal build-ups within the Arctic Circle: morphology and sedimentary dynamics under extreme environmental seasonality. Sedimentology 41:963-984

Gambi MC, Giangrande A, Martinelli M et al (1985) Polychaetes of a Posidonia oceanica bed off Sardinia (Italy): spatio-temporal distribution and feeding guild analysis. Sci Mar 59:129-141

Geyer WR, Signell R (1990) Measurements of tidal flow around a headland with a shipboard acoustic Doppler current profiler. J Geophys Res 95:3169-3197

Giaccone G (1972-1973) Elementi di botanica marina I e II. [Pubblicazioni dell'Istituto Botanico di Trieste. Serie Didattica]. Trieste, Italy, pp 358

Graham A (1988) Molluscs: prosobranch and pyramidellid gastropods. [Synopses of the British Fauna (New Series) No. 2]. Brill, Leiden. pp 662

Grall J, Glemarec M (1997) Biodiversite des fonds de maerl en Bretagne: approache fonctionnelle et impacts anthropogeniques. Vie Milieu 47:339-349

Grall J, Hall-Spencer JM (2003) Problems facing maerl conservation in Brittany. Aquat Conserv Mar Freshw Ecosyst 13:S55-S64

Grall J, Le Loc'h F, Guyonnet B et al (2006) Community structure and food web based on stable isotopes $\left(\delta^{15} \mathrm{~N}\right.$ and $\left.\delta^{13} \mathrm{C}\right)$ analysis of a North Eastern Atlantic maerl bed. J Exp Mar Biol Ecol 338:1-15

Guichard F, Bourget E (1998) Topographic heterogeneity, hydrodynamics, and benthic community structure: a scale-dependent cascade. Mar Ecol Prog Ser 171:59-70

Hall-Spencer J (1998) Conservation issues relating to maerl beds as habitats for molluscs. J Conchol 2:S271-S286

Hall-Spencer JM, Moore PG (2000) Scallop dredging has profound longterm impacts on maerl habitats. ICES J Mar Sci 57:1407-1415

Hamel G, Lemoine M (1953) Corallinacóes de France et d'Afrique du Nord. Archs Mus Hist Nat, Pris, Ser 7, 1:15-136, 23 pl

Harris PT, Tsuji Y, Marshall JF et al (1996) Sand and rhodolith-gravel entrainment on the mid- to outer-shelf under a western boundary current: Fraser Island continental shelf, eastern Australia. Mar Geol 129:313-330 
Hinojosa-Arango G, Riosmena-Rodriguez R (2004) Influence of rhodolith-forming species and growth-form on associated fauna of rhodolith beds in the Central-West Gulf of California, Mexico. Mar Ecol 25:109-127

Howege HM (1998) The structure of the molluscan assemblages of sea-grass beds in the Maltese Islands. PhD thesis, University of Malta

Hughes RN (1986) A functional biology of marine gastropods. Croom Helm, London

Jackson CM, Kamenos NA, Moore PG, Young M (2004) Meiofaunal bivalves in maerl and other substrata: their diversity and community structure. Ophelia 58:49-60

Jones CG, Lawton JH, Shachak M (1994) Organisms as ecosystem engineers. Oikos 69:373-386

Kamenos NA, Moore PG, Hall-Spencer JM (2004a) Maerl grounds provide both refuge and high growth potential for juvenile queen scallops (Aequipecten opercularis L.). J Exp Mar Biol Ecol 313:241-254

Kamenos NA, Moore PG, Hall-Spencer JM (2004b) Small-scale distribution of juvenile gadoids in shallow inshore waters: what role does maerl play? ICES J Mar Sci 61:422-429

Keegan BF (1974) The macrofauna of maerl substrates on the west coast of Ireland. Cah Biol Mar 15:513-530

Kohn AJ (1983) Feeding biology of gastropods. In: Saleuddin ASM, Wilbur KM (eds) The mollusca Vol. 5. Physiology, part 2. Academic, New York, pp 1-63

Krumbein WC (1941) Measurement and geological significance of shape and roundness of sedimentary particles. J Sediment Petrol 11:64-72

Littler MM, Littler DS, Hanisak MD (1991) Deep-water rhodolith distribution, productivity, and growth history at sites of formation and subsequent degradation. J Exp Mar Biol Ecol 150:163-182

Marrack EC (1999) The relationship between water motion and living rhodolith beds in southwestern Gulf of California, Mexico. Palaios 14:159-171

Marshall SM, Orr AP (1960) Feeding and nutrition. In: Waterman T H (ed) The physiology of Crustacea, Volume I: Metabolism and growth. Academic, New York

Martin S, Clavier J, Chauvaud L, Thouzeau G (2007) Community metabolism in temperate maerl beds. II. Nutrient fluxes. Mar Ecol Prog Ser 335:31-41

Massutí E, Reñones O, Carbonell A et al (1996) Demersal fish communities exploited on the continental shelf and slope off Majorca (Balearic Islands, NW Mediterranean). Vie Milieu 46:45-55

Menge BA (1976) Organization of the New England rocky intertidal community: Role of predation, competition, and environmental heterogeneity. Ecol Monogr 46:355-393

Menge BA, Lubchenco J, Ashkenas LR (1985) Diversity, heterogeneity and consumer pressure in a tropical rocky intertidal community. Oecologia 65:394-405

Morton B (1983) Feeding and digestion in Bivalvia. In: Saleuddin ASM, Wilbur KM (eds) The mollusca Vol. 5. Physiology, part 2. Academic, New York, pp 65-147
Nicol JAC (1967) The biology of marine animals. Wiley, New York

Peña V, Bárbara I (2008a) Biological importance of an Atlantic European maerl bed off Benencia Island (northwest Iberian Peninsula). Bot Mar 51:493-505

Peña V, Bárbara I (2008b) Maerl community in the north-west Iberian Peninsula: a review of floristic studies and long-term changes. Aquat Conserv Mar Freshw Ecosyst 18:339-366

Pérès JM (1967) The Mediterranean benthos. Oceanogr Mar Biol Annu Rev 5:449-533

Pérès JM (1982) Structure and dynamics of assemblages in the benthal. In: Kinne O (ed) Marine ecology Vol. 5, part 1. Wiley, New York, pp 119-185

Prager EJ, Ginsburg RN (1989) Carbonate nodule growth on Florida's outer shelf and its implications for fossil interpretations. Palaios 4:310-317

Preda A (1908) Floridae. In: Flora Italica Cryptogoma Part 2: Algae. Roveca S. Coscione

Riul P, Targino CH, Da Nobrega Farias J et al (2008) Decrease in Lithothamnion sp. (Rhodophyta) primary production due to the deposition of a thin sediment layer. J Mar Biol Assoc UK 88:1719

Riul P, Lacouth P, Pagliosa PR et al (2009) Rhodolith beds at the easternmost extreme of South America: Community structure of an endangered environment. Aquat Bot 90:315-320

Rowe GA, Sheader M, Jensen AC (1990) The infauna of the Handfast Point maerl bed [Report No. SUDO/TEC/90/16C] Nature Conservancy Council, Peterborough, pp 57

Scipione MB (1999) Amphipod biodiversity in the foliar stratum of shallow-water Posidonia oceanica beds in the Mediterranean Sea. In: Schram F R, von Vupel Klein J C (eds) Crustaceans and the biodiversity crisis. Proceedings of the 4th International Crustacean Congress, Amsterdam, July 20-24, pp 649-662

Steller DL, Foster MS (1995) Environmental factors influencing distribution and morphology of rhodoliths in Bahía Concepción, B.C.S., México. J Exp Mar Biol Ecol 194:201-212

Steller DL, Riosmena-Rodríguez R, Foster MS et al (2003) Rhodolith bed diversity in the Gulf of California: the importance of rhodolith structure and consequences of anthropogenic disturbances. Aquat Conserv Mar Freshw Ecosyst 13:S5-S20

Steller DL, Hernández-Ayón JM, Riosmena-Rodríguez R et al (2007) Effect of temperature on photosynthesis, growth and calcification rates of the free-living coralline alga Lithophyllum margaritae. Cienc Mar 33:441-456

Steneck RS (1986) The ecology of coralline algal crusts: convergent patterns and adaptive strategies. Annu Rev Ecol Syst 17:273-303

Vidondo B, Duarte CM (1995) Seasonal growth of Codium bursa, a slow-growing Mediterranean macroalga: in situ experimental evidence of nutrient limitation. Mar Ecol Prog Ser 123:185-191

Wilson S, Blake C, Berges JA et al (2004) Environmental tolerances of free-living coralline algae (maerl): Implications for European marine conservation. Biol Conserv 120:279-289

Wolanski E, Hamner WM (1988) Topographically controlled fronts in the ocean and their biological influence. Science 241:177-181 
Appendix 1 The depth (m) and geographic position (longitude and latitude are given in $\operatorname{deg}^{\circ}$ min' sec') of the stations where live rhodoliths were present are given. The percentage mass of the live rhodoliths at each station is also given, except for stations G4 and H3 where only a very small amount of live rhodoliths and no non-biogenic sediment were collected

\begin{tabular}{|c|c|c|c|}
\hline Station code & Depth (m) & $\begin{array}{c}\text { Geographical } \\
\text { Position }\end{array}$ & $\begin{array}{c}\text { \% mass } \\
\text { rhodoliths }\end{array}$ \\
\hline A1 & 67 & $\begin{array}{l}3602.45 \mathrm{~N} \\
1420.59 \mathrm{E}\end{array}$ & 3.63 \\
\hline $\mathrm{A} 2$ & 75 & $\begin{array}{l}3602.86 \mathrm{~N} \\
1420.94 \mathrm{E}\end{array}$ & 1.45 \\
\hline B1 & 51 & $\begin{array}{l}3601.38 \mathrm{~N} \\
1421.93 \mathrm{E}\end{array}$ & 11.45 \\
\hline B2 & 66 & $\begin{array}{l}3601.87 \mathrm{~N} \\
1422.26 \mathrm{E}\end{array}$ & 25.88 \\
\hline B3 & 74 & $\begin{array}{l}3602.23 \mathrm{~N} \\
1422.69 \mathrm{E}\end{array}$ & 13.81 \\
\hline $\mathrm{C} 1$ & 31 & $\begin{array}{l}3600.61 \mathrm{~N} \\
1422.70 \mathrm{E}\end{array}$ & 0.07 \\
\hline $\mathrm{C} 2$ & 38 & $\begin{array}{l}3601.04 \mathrm{~N} \\
1423.09 \mathrm{E}\end{array}$ & 1.18 \\
\hline C3 & 57 & $\begin{array}{l}3601.41 \mathrm{~N} \\
1423.50 \mathrm{E}\end{array}$ & 7.54 \\
\hline $\mathrm{C} 4$ & 70 & $\begin{array}{l}3601.87 \mathrm{~N} \\
1423.72 \mathrm{E}\end{array}$ & 14.97 \\
\hline D3 & 53 & $\begin{array}{l}3600.99 \mathrm{~N} \\
1424.57 \mathrm{E}\end{array}$ & 12.19 \\
\hline
\end{tabular}




\begin{tabular}{|c|c|c|c|}
\hline D4 & 67 & $\begin{array}{l}3601.35 \mathrm{~N} \\
1424.95 \mathrm{E}\end{array}$ & 20.18 \\
\hline E3 & 44 & $\begin{array}{l}3600.40 \mathrm{~N} \\
1425.31 \mathrm{E}\end{array}$ & 5.23 \\
\hline E4 & 58 & $\begin{array}{l}3600.78 \mathrm{~N} \\
1425.62 \mathrm{E}\end{array}$ & 1.19 \\
\hline E5 & 70 & $\begin{array}{l}3601.28 \mathrm{~N} \\
1426.02 \mathrm{E}\end{array}$ & 35.79 \\
\hline F4 & 46 & $\begin{array}{l}3600.09 \mathrm{~N} \\
1425.84 \mathrm{E}\end{array}$ & 18.35 \\
\hline F6 & 61 & $\begin{array}{l}3600.83 N \\
1426.51 E\end{array}$ & 35.8 \\
\hline G4 & 51 & $\begin{array}{l}3558.69 \mathrm{~N} \\
1425.95 \mathrm{E}\end{array}$ & - \\
\hline G5 & 54 & $\begin{array}{l}3559.00 \mathrm{~N} \\
1426.28 \mathrm{E}\end{array}$ & 2.83 \\
\hline G7 & 66 & $\begin{array}{l}3600.30 \mathrm{~N} \\
1426.98 \mathrm{E}\end{array}$ & 38.84 \\
\hline G8 & 75 & $\begin{array}{l}3600.70 \mathrm{~N} \\
1427.43 \mathrm{E}\end{array}$ & 32.73 \\
\hline H2 & 53 & $\begin{array}{l}3558.85 \mathrm{~N} \\
1426.61 \mathrm{E}\end{array}$ & 5.82 \\
\hline H3 & 55 & $\begin{array}{l}3559.24 \mathrm{~N} \\
1426.90 \mathrm{E}\end{array}$ & - \\
\hline
\end{tabular}




\begin{tabular}{|c|c|c|c|}
\hline H4 & 55 & $\begin{array}{l}3559.72 \mathrm{~N} \\
1427.29 \mathrm{E}\end{array}$ & 14.79 \\
\hline H5 & 60 & $\begin{array}{l}3600.11 \mathrm{~N} \\
1427.61 \mathrm{E}\end{array}$ & 6.51 \\
\hline H6 & 87 & $\begin{array}{l}3600.48 \mathrm{~N} \\
1428.07 \mathrm{E}\end{array}$ & 18.56 \\
\hline I1 & 49 & $\begin{array}{l}3558.13 N \\
1426.78 E\end{array}$ & 2.01 \\
\hline I2 & 47 & $\begin{array}{l}3558.51 \mathrm{~N} \\
1427.17 \mathrm{E}\end{array}$ & 2.08 \\
\hline I3 & 54 & $\begin{array}{l}3558.96 \mathrm{~N} \\
1427.52 \mathrm{E}\end{array}$ & 10.88 \\
\hline I4 & 62 & $\begin{array}{c}3559.29 \mathrm{~N} \\
1427.86 \mathrm{E}\end{array}$ & 18.41 \\
\hline I5 & 65 & $\begin{array}{l}3559.71 \mathrm{~N} \\
1428.22 \mathrm{E}\end{array}$ & 0.03 \\
\hline I6 & 75 & $\begin{array}{l}3600.10 \mathrm{~N} \\
1428.60 \mathrm{E}\end{array}$ & 0.02 \\
\hline I7 & 102 & $\begin{array}{l}3600.27 N \\
1428.76 E\end{array}$ & 8.68 \\
\hline J3 & 60 & $\begin{array}{l}3558.55 \mathrm{~N} \\
1428.61 \mathrm{E}\end{array}$ & 5.46 \\
\hline $\mathrm{J} 4$ & 66 & $\begin{array}{l}3558.92 \mathrm{~N} \\
1429.02 \mathrm{E}\end{array}$ & 28.84 \\
\hline
\end{tabular}




\begin{tabular}{|c|c|c|c|}
\hline J5 & 72 & $\begin{array}{l}3559.32 \mathrm{~N} \\
1429.32 \mathrm{E}\end{array}$ & 27.98 \\
\hline J6 & 97 & $\begin{array}{c}3559.69 \mathrm{~N} \\
1429.70 \mathrm{E}\end{array}$ & 22.74 \\
\hline K1 & 46 & $\begin{array}{l}3557.08 \mathrm{~N} \\
1429.19 \mathrm{E}\end{array}$ & 10.48 \\
\hline K2 & 56 & $\begin{array}{l}3557.49 \mathrm{~N} \\
1429.49 \mathrm{E}\end{array}$ & 4.36 \\
\hline K3 & 71 & $\begin{array}{c}3557.93 \mathrm{~N} \\
1429.80 \mathrm{E}\end{array}$ & 11.63 \\
\hline K4 & 90 & $\begin{array}{l}3558.31 \mathrm{~N} \\
1430.09 \mathrm{E}\end{array}$ & 36.07 \\
\hline K5 & 103 & $\begin{array}{l}3558.76 \mathrm{~N} \\
1430.52 \mathrm{E}\end{array}$ & 10.44 \\
\hline L1 & 83 & $\begin{array}{c}3556.62 \mathrm{~N} \\
1430.86 \mathrm{E}\end{array}$ & 8.62 \\
\hline
\end{tabular}


Appendix 2 Classified species list of the species collected using grab sampling during the seasonal sampling at Sites 1 and 2 between July 1996 and April 1998

\begin{tabular}{|c|c|c|}
\hline Algae & Gastropoda & Bivalvia \\
\hline ?Aglaothamnion sp. & Alvania beani & Aequipecten opercularis \\
\hline ?Aglaozonia sp. & Alvania discors & Astarte fusca \\
\hline Aphanocapsa litoralis & Ascobulla fragilis & Chlamys flexuosa \\
\hline ?Aphanocapsa sp. & Barleeia unifasciata & Ctena decussata \\
\hline Audouinella saviana & Bittium jadertinum & Digitaria digitaria \\
\hline Audouinella cf. virgatula & Bittium latreillii & Diplodonta apicalis \\
\hline Bolbocoleon piliferum & Caecum trachea & Glans trapezia \\
\hline Botryocladia microphysa & Calyptraea chinensis & Glycymeris glycymeris \\
\hline cf. Callithamnion sp. & Cerithiopsis fayalensis & Gonilia calliglypta \\
\hline Calothrix sp. & Cerithiopsis tubercularis & Gouldia minima \\
\hline Ceramium tenerrimum & Cerithium lividulum & Limatula subauriculata \\
\hline Chondria tenuissima & Chauvetia turritellata & Lissopecten hyalinus \\
\hline Chroodactylon ornatum & Clathromangelia quadrillum & Modiolus adriaticus \\
\hline Cladophora patentiramea & Colubraria reticulata & Neolepton sulcatulum \\
\hline Codium bursa & Cosmotriphora pseudocanarica & Nucula nitidosa \\
\hline ?Cordylecladia sp. & Crassopleura incrassata & Palliolum incomparabile \\
\hline Crouania attenuata & Crepidula unguiformis & Pseudochama gryphina \\
\hline Cryptonemia sp. & Dermomurex scalaroides & Pteromeris minuta \\
\hline Cryptonemia tuniformis & Fusinus rudis & Solemya togata \\
\hline Cystoseira corniculata & Gibbula fanulum & Striarca lacteal \\
\hline Cystoseira cf. dubia & Haedropleura secalina & Tellina balaustina \\
\hline Cystoseira sp. & Haminoea hydatis & Tellina pygmaea \\
\hline Cystoseira spinosa & Jujubinus exasperatus & Thracia convexa \\
\hline Dasya corallicola & Jujubinus ?montagui/tumidulus & Thracia distorta \\
\hline Dasya corymbifera & Jujubinus striatus & Venericardia antiquata \\
\hline Dasya punicea & Melanella polita & \\
\hline Dasya rigidula & Metaxia metaxae & Polyplacophora \\
\hline Dictyota dichotoma & Mitrella scripta & Acanthochitona fascicularis \\
\hline Dictyota ?linearis/mediterranea & Mitrolumna olivoidea & Callochiton septemvalvis \\
\hline Dictyota sp. & Monophorus cf. perversus & Leptochiton africanus \\
\hline Ectocarpus sp. & Muricopsis cristata & \\
\hline Lithophyllum sp. & Nanobalcis nana & Crustacea \\
\hline Flabellia petiolata & Natica dillwynii & Alpheus sp. \\
\hline Gelidiella sp. & Ocinebrina aciculata & Achaeus cranchii \\
\hline
\end{tabular}




\begin{tabular}{|c|c|c|}
\hline Algae & Gastropoda & Crustacea \\
\hline Gelidium sp. & Odostomia conoidea & Ampelisca sp. \\
\hline Gigartina teedei & Opisthobranchia sp. & Amphitoe ramondi \\
\hline Gracilaria dura & Phalium granulatum & ?Anapagurus breviaculeatus \\
\hline Gracilaria sp. & Rissoina bruguieri & ?Apherusa bispinosa \\
\hline Halimeda tuna & Turritella turbona & Apseudes talpa \\
\hline Halopithys incurva & Vermetidae sp. & Athanas nitescens \\
\hline Halopithys pinastroides & Vexillum ebenus & Calcinus tubularis \\
\hline Halopteris filicina & Vexillum savignyi & Ceradocus orchestiipes \\
\hline Halopteris scoparia & Vitreolina philippi & Ceradocus semiserratus \\
\hline Hydrolithon sp. 1 & Volvarina mitrella & Cestopagurus timidus \\
\hline Hydrolithon sp. 2 & Williamia gussonii & Cheirocratus sundevalli \\
\hline Hypoglossum hypoglossoides & & Cirolanidae sp. 1 \\
\hline Jania adhaerens & Annelida & Cirolanidae sp. 2 \\
\hline Jania rubens & Amage adspersa & Copepoda sp. \\
\hline ?Laurencia minuta & Aponuphis fauveli & Cyathura carinata \\
\hline Laurencia obtusa & Branchiomma vesiculosum & Dexamine spinosa \\
\hline Laurencia cf paniculata & Capitella capitata & Ebalia edwardsii \\
\hline Laurencia sp. 1 & Capitomastus minimus & Eurydice truncata \\
\hline Laurencia sp. 2 & Cirratulus filiformis & Eurynome aspera \\
\hline Leathesia sp. & Chone acustica & Eusirus longipes \\
\hline Lyngbya sp. & Eunice vittata & Galathea intermedia \\
\hline Meredithia microphylla & Eusyllis lamelligera & Gammarella fucicola \\
\hline Microdictyon tenuius & Fabricia sp. & Gnathia vorax \\
\hline Osmundea pelagosae & Filograna sp. & Gourretia minor \\
\hline Peyssonnelia sp. & Glycera convoluta & Harpinia antennaria \\
\hline Peyssonneliaceae sp. & Glycera sp. & Hippolyte sp. \\
\hline Phaeophila dendroides & Harmothoe longisetis & Hippomedon oculatus \\
\hline Polysiphonia elongata & Harmothoe sp. & Hippomedon sp. \\
\hline Polysiphonia mottei & Hyalinoecia grubii & Hyale camptonyx \\
\hline Polysiphonia cf. ornata & Jasmineira sp. & Inachus ?thoracicus/aguiarii \\
\hline Polysiphonia ruchingeri & Josephella sp. 1 & Iphimedia minuta \\
\hline Polysiphonia setacea & Josephella sp. 2 & Joeropsis brevicornis \\
\hline Polysiphonia cf. setigera & Lumbrineris gracilis & Lembos viguieri \\
\hline Polysiphonia sp. 1 & Lumbrineris impatiens & ?Leptocheirus bispinosus \\
\hline Polysiphonia sp. 2 & Lumbrineris sp. 1 & Leptocheirus pectinatus \\
\hline Polysiphonia spinosa & Lumbrineris sp. 2 & Leptocheirus sp. \\
\hline
\end{tabular}




\begin{tabular}{|c|c|c|}
\hline Algae & Annelida & Crustacea \\
\hline Polysiphonia cf. urceolata & Lysidice ninetta & Leptochelia savignyi \\
\hline Rhizoclonium kochianum & Marphysa fallax & ?Leucothoe incisa \\
\hline Rivularia polyotis & Myxicola infundibulum & ?Leucothoe spinicarpa \\
\hline Rytiphlaea tinctoria & Nematonereis unicornis & Liljeborgia dellavallei \\
\hline Scytosiphon cf. lomentaria & Nereidae sp. & Liocarcinus corrugatus \\
\hline ?Seirospora sp. & Nereiphylla paretti & Liocarcinus maculatus \\
\hline Spatoglossum solierii & Nereis rava & Liocarcinus sp. \\
\hline Sphacelaria cirrosa & Nereis sp. & Liocarcinus zariquieyi \\
\hline Sphacelaria sp. & Notomastus profundus & Lysianassa costae \\
\hline Spyridia filamentosa & Oridia armandi & Lysianassa longicornis \\
\hline Stilophora rhizodes & Paraonidae sp. & Maera grossimana \\
\hline Streblocladia collabens & Pelogenia arenosa & Metaphoxus fultoni \\
\hline Ulothrix subflaccida & Phyllochaetopterus socialis & Mysidacea sp. 1 \\
\hline Valonia utricularis & Phyllodocidae sp. & Nebalia bipes \\
\hline Vidalia volubilis & Pista cristata & Ostracoda sp. 1 \\
\hline Zanardinia sp. & Placostegus sp. & Pagurus excavatus \\
\hline \multirow[t]{2}{*}{ Zonaria tournefortii } & Platynereis dumerilii & Pagurus sp. \\
\hline & Platynereis sp. & Palicus caronii \\
\hline Echinodermata & Pomatoceros sp. & Parthenope massena \\
\hline Antedon mediterranea & Sabellidae sp. & Pereionotus testudo \\
\hline Echinocyamus pusillus & Scalibregma inflatum & Pisa cf. armata \\
\hline Genocidaris maculata & Schistomeringos rudolphii & Processa sp. \\
\hline Luidia ciliaris & Serpula sp. 1 & Socarnes filicornis \\
\hline Neolampas rostellata & Serpula sp. 2 & Thoralus cranchii \\
\hline Ophiuroid sp. & Spiophanes kroyeri & Upogebia cf. mediterranea \\
\hline \multirow[t]{2}{*}{ Stylocidaris affinis } & Spirorbis sp. & Urothoe elegans \\
\hline & Syllis amica & \\
\hline Sipunculida & Syllis prolifera & Porifera \\
\hline Aspidosiphon muelleri & Syllis sp. 1 & Spg. 1 \\
\hline \multirow[t]{2}{*}{ Sipunculus nudus } & Syllis sp. 2 & Spg. 2 \\
\hline & Syllis sp. 3 & Spg. 3 \\
\hline Brachiopoda & Tharyx sp. & Spg. 4 \\
\hline \multirow[t]{2}{*}{ Argyrotheca cuneata } & Thelepus cf cincinnatus & Spg. 5 \\
\hline & Vermiliopsis sp. & Spg. 6 \\
\hline Cephalochordata & & Spg. 7 \\
\hline Branchiostoma lanceolatum & & Spg. 8 \\
\hline
\end{tabular}




\begin{tabular}{|lll|}
\hline Ascidia - Urochordata & Bryozoa & Porifera \\
\hline Ascidia sp. & Aetea sp. & Spg. 9 \\
Red ascidian sp. & Ascophoran cheilostome sp. 1 & Spg. 10 \\
Rhopalaea neapolitana & Celleporina sp. & Spg. 11 \\
& Chorizopora brongniartii & Spg. 12 \\
Sarcodina & Cyclostome sp. 2 & Spg. 13 \\
Cibicides sp. & Entalophoroecia sp. & Spg. 14 \\
Miniacina miniacea & ?Filicrisia sp. & \\
& Lichenoporid cyclostome sp. 1 & \\
& Microporella pseudomarsupiata & Cnidaria \\
& Mollia patellaria & Actinaria sp. \\
& ?Plagioecia sp. & Hydroid sp. \\
& Reptadeonella violacea & Nausithoidae sp. \\
& Rhynchozoon sp. & \\
& Schizomavella rudis & \\
& Tubulipora sp. & \\
\hline
\end{tabular}

